\title{
Phytotechnologies for Site Remediation
}

\author{
Valentina Pidlisnyuk, Ganga M. Hettiarachchi, \\ Zeljka Zgorelec, Melissa Prelac, Nikola Bilandžija, \\ Lawrence C. Davis, and Larry E. Erickson
}

\begin{abstract}
Phytotechnologies for inorganic contaminants include phytoextraction, phytostabilization, phytotransformation, and phytohydraulics. Soil amendments may be added to increase contaminant solubility when phytoextraction is implemented. For phytostabilization soil amendments may be added to reduce contaminant availability, such as transformation to a less soluble compound. Phytotransformation is the process of changing the contaminant to another form to reduce risk of movement or toxicity. Phytohydraulics may be applied with phytostabilization when the design includes evapotranspiration to reduce transport of the contaminants away from the point of contamination. Plants used for phytostabilization should be able to grow well in the contaminated soil, produce a product of value and commercial interest, and evapotranspire sufficient water to achieve containment of the contaminants. The uptake and translocation of the contaminants to aboveground biomass should be small enough to allow the plant biomass to be used for a commercial purpose. Miscanthus is among the most promising energy crops for phytoremediation: it grows well in contaminated soil, evaptranspires large quantities of water, and produces high-quality cellulose. The use of soil amendments can help to minimize contaminant uptake and improving soil quality is an important issue. Several other energy crops that have good potential for phytostabilization application are introduced in this chapter as well.
\end{abstract}

\section{CONTENTS}

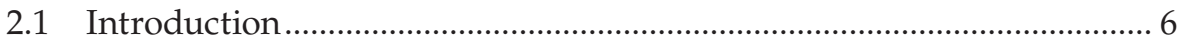

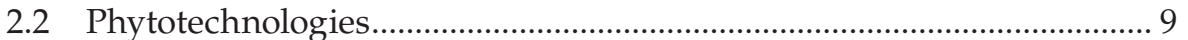

2.3 Phytostabilization of Arable Land Contaminated with

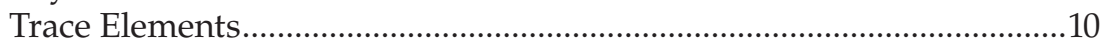

2.4 Bioenergy Crops and Phytostabilization Options ....................................11 
2.5 M. $\times$ giganteus as an Effective Phytoagent................................................ 19

2.5.1 Miscanthus Tolerance to Metals and Removal Capacity ............ 20

2.5.2 Changes in Soil Parameters Induced by Miscanthus

Phytoremediation .......................................................................... 21

2.6 Miscanthus Phytotechnology in Action ...................................................22

2.6.1 M. × giganteus Application for Phytoremediation of Trace

Elements' Contaminated Mining Soil, Tekeli, Kazakhstan........22

2.6.2 M. × giganteus Application for Phytoremediation of

Post-Industrial Soil Contaminated with Trace Elements,

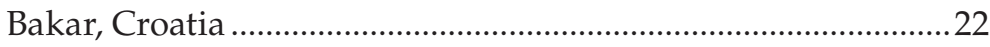

2.6.3 Field Study Results, Fort Riley, Kansas, USA …………...............2 23

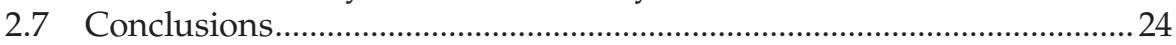

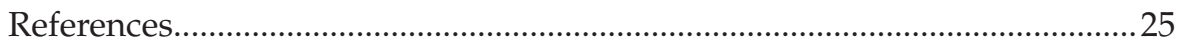

\subsection{Introduction}

Phytoremediation technology was established as an environment-friendly concept to restore polluted sites before 1990, and a year later the term was used. Generally, phytoremediation technology can be divided into six subtypes depending on the contaminant origin and the mechanisms of restoration (USEPA, 1998). In order to remediate sites polluted by contaminants of inorganic origin (mainly trace elements) the following processes are proposed (USEPA, 1998):

1. phytoextraction - remediation mechanism is based on the uptake of contaminant by roots and its transmigration to the aboveground tissues (leaves, stems, branches);

2. rhizofiltration - remediation mechanism is represented by the accumulation of contaminants in roots;

3. phytostabilization - remediation mechanism is based on the contaminant immobilization in soil by plant root exudates.

In case of remediation sites polluted by contaminants of organic origin the following processes are in the focus (USEPA, 1998):

4. phytodegradation - remediation mechanism is based on absorbing the contaminants by roots and converting them by plant enzymatic activity to safe compounds;

5. rhizodegradation - remediation mechanism is based on the provision of favorable environmental conditions for microorganisms to 
be able to degrade the contaminants in the rhizosphere, plant roots release organic compounds (nutrients, enzymes, organic acids, etc.) to reach favorable conditions;

6. phytovolatilization - remediation mechanism is based on absorbing the contaminants by roots and releasing them to atmosphere.

The term phytotechnologies, which replaces the earlier term phytoremediation, is also known as green-remediation, and in general, means using plants to degrade, extract, contain, transform into less harmful forms, or immobilize contaminants in soil, water, or air with inorganic or organic compounds. Phytotechnology mechanisms and technological effects are summarized in Table 2.1. Some phytotechnologies have gained public acceptance compared to other remediation techniques and multiple related terms, such as phytomanagement, have been introduced. As far as phytomanagement is concerned, this concept is newer and covers economic benefits (Robinson et al., 2009). In addition to using plants to reduce the risks posed by soil contamination, the concept

\section{TABLE 2.1}

Phytotechnology Mechanisms and Effect of Technology

\begin{tabular}{|c|c|c|}
\hline $\begin{array}{l}\text { Effect of } \\
\text { Technology }\end{array}$ & $\begin{array}{c}\text { Phytotechnology } \\
\text { Mechanism }\end{array}$ & Definition \\
\hline \multirow[t]{3}{*}{$\begin{array}{l}\text { Reduce } \\
\text { contaminant } \\
\text { concentration } \\
\text { (extraction, } \\
\text { degradation) }\end{array}$} & $\begin{array}{l}\text { Phytoextraction/ } \\
\text { Phytomining/ } \\
\text { Phytoaccumulation }\end{array}$ & $\begin{array}{l}\text { The removal of inorganic contaminants from the } \\
\text { soil through plant uptake, and subsequent } \\
\text { harvest and removal of biomass. } \\
\text { Phytoextraction, phytomining, or } \\
\text { phytoaccumulation are typically used to remove } \\
\text { metals from the soil (e.g., As extraction by Pteris } \\
\text { vittata (brake fern) (Ma et al., 2001); Ni by } \\
\text { Alyssum species (Li et al., 2003). }\end{array}$ \\
\hline & $\begin{array}{l}\text { Phytodegradation/ } \\
\text { Phytotransformation }\end{array}$ & $\begin{array}{l}\text { The breakdown of contaminants by the metabolic } \\
\text { processes in a plant. Also includes the breakdown } \\
\text { of contaminants in the soil by enzymes or other } \\
\text { products produced by the plant. Primarily used } \\
\text { for organic contaminants. }\end{array}$ \\
\hline & $\begin{array}{l}\text { Rhizofiltration/ } \\
\text { Rhizodegradation }\end{array}$ & $\begin{array}{l}\text { The breakdown or degradation of organic } \\
\text { contaminants in the soil. The contaminants are } \\
\text { either adsorbed onto the root surface or are } \\
\text { absorbed by the plant roots. Due to enhanced } \\
\text { microbial activity in the rhizosphere (the zone of } \\
\text { soil influenced by the roots), the contaminants are } \\
\text { broken down. This process can be enhanced by } \\
\text { fertilization. }\end{array}$ \\
\hline
\end{tabular}


Phytotechnology with Biomass Production

\section{TABLE 2.1 (Continued)}

Phytotechnology Mechanisms and Effect of Technology

\begin{tabular}{|c|c|c|}
\hline $\begin{array}{l}\text { Effect of } \\
\text { Technology }\end{array}$ & $\begin{array}{l}\text { Phytotechnology } \\
\text { Mechanism }\end{array}$ & Definition \\
\hline \multirow{3}{*}{$\begin{array}{l}\text { Reduce } \\
\text { contaminant } \\
\text { bioavailability } \\
\text { without } \\
\text { reducing total } \\
\text { concentrations } \\
\text { (immobilization) }\end{array}$} & Phytovolatilization & $\begin{array}{l}\text { The uptake of contaminants by plants and } \\
\text { release them into the atmosphere as they } \\
\text { transpire water (direct phytovolatilization). } \\
\text { Contaminant is removed from the soil and may } \\
\text { be degraded as it moves through the plant's } \\
\text { vascular system before final removal from the } \\
\text { system. This can be used for both organic (e.g., } \\
\text { volatile organic compounds) and inorganic } \\
\text { contaminants (e.g., Se, and Hg). Additionally, } \\
\text { contaminants can be volatilized from soil due to } \\
\text { plant root activities (indirect } \\
\text { phytovolatilization) (Limmer \& Burken, 2016) }\end{array}$ \\
\hline & $\begin{array}{l}\text { Phytosequestration/ } \\
\text { Phytostabilization }\end{array}$ & $\begin{array}{l}\text { This process sequesters, or reduces, contaminant } \\
\text { bioavailability through precipitation or } \\
\text { immobilization of contaminants in the soil, on } \\
\text { the root surface, or within the root tissues } \\
\text { (Laperche et al., 1996). }\end{array}$ \\
\hline & $\begin{array}{l}\text { Phytotransformation } \\
\text { (inorganics) }\end{array}$ & $\begin{array}{l}\text { The transformation of contaminants } \\
\text { by the metabolic processes in a } \\
\text { plant. It also includes the } \\
\text { transformation of contaminants in } \\
\text { the soil by enzymes or other } \\
\text { products produced by the plant. } \\
\text { This can be used for nutrients and } \\
\text { other inorganic contaminants. }\end{array}$ \\
\hline \multirow[t]{2}{*}{$\begin{array}{l}\text { Reduce } \\
\text { contaminant } \\
\text { movement } \\
\text { (containment) }\end{array}$} & $\begin{array}{l}\text { Phytostabilization } \\
\text { (Phytorestoration, } \\
\text { In place inactivation) }\end{array}$ & $\begin{array}{l}\text { Plants are used to stabilize contaminated soils } \\
\text { or sediments, thus protecting them from } \\
\text { transport by wind or water erosion. The } \\
\text { main function is to contain the contaminated } \\
\text { material. However, this is usually combined } \\
\text { with adding soil amendment to reduce } \\
\text { contaminant movement in soil } \\
\text { (e.g., phytostabilzation of Pb contaminated } \\
\text { military site soil using Miscanthus in } \\
\text { combination with P amendments (Alasmary } \\
\text { et al., 2020)). }\end{array}$ \\
\hline & Phytohydraulics & $\begin{array}{l}\text { This process is used to limit the movement } \\
\text { of contaminants with water. Plants are } \\
\text { used to increase evapotranspiration, } \\
\text { thereby controlling soil water and } \\
\text { contaminant movement. This mechanism } \\
\text { contains the contaminant by modifying } \\
\text { site hydrology to reduce the vertical or } \\
\text { horizontal movement of water in the soil } \\
\text { (Narayanan et al., 1999). }\end{array}$ \\
\hline
\end{tabular}


includes converting the obtained biomass into useful products (Evangelou et al., 2015; Robinson et al., 2009); in other words, "phytomanagement is a combination of phytoremediation and sustainable site management with economic return" (Conesa et al., 2012; Pandey \& Bajpai, 2019).

The goal of this section is to provide an overview of various plant-based techniques for remediation of contaminated soils and to introduce research and applications of plant cultivation in contaminated areas to obtain biomass, with emphasis on Miscanthus as the phytoagent (Pidlisnyuk et al., 2014).

\subsection{Phytotechnologies}

The two most commonly used phytotechnologies for inorganic contaminants are phytoextraction and phytostabilization. In the phytoextraction process the plant's ability to accumulate trace elements is important. Based on the relative uptake and bioaccumulation potential, plants can be grouped into three categories: excluders, indicators, and accumulators (Adriano, 2001; Hunt et al., 2014) (see Figure 2.1).

The ability of plants to accumulate trace elements from the soil can be estimated by the enrichment coefficient (EC) or the bioconcentration factor, which are expressed as the ratio of defined trace element concentrations in the plant material (mg kg-1 of dry matter) and in the soil ( $\mathrm{mg} \mathrm{kg}^{-1}$ of dry soil). In addition, translocation factor (TLF) value reflects the levels of plants' phytoextraction potential accounting as a ratio of the contaminants' concentrations in the aboveground biomass to their concentration in roots

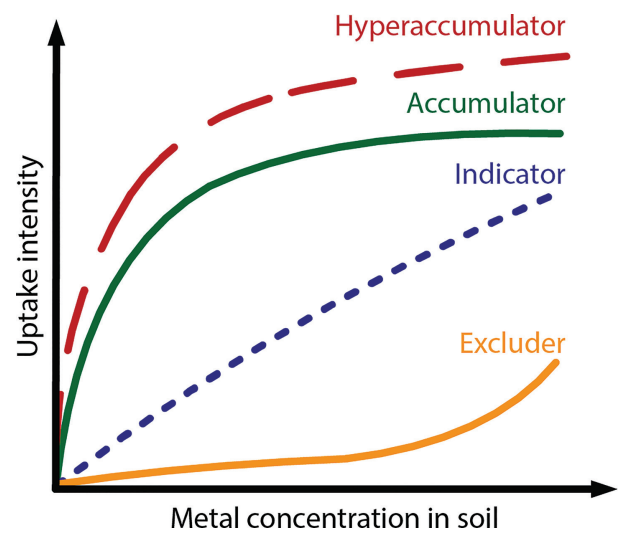

FIGURE 2.1

Three groups of plant categories based on their uptake behavior of trace elements: excluders, indicators, and accumulators. (Modified from Hunt et al., 2014.) 
(Baker, 1981; Mamirova et al., 2020). Malayeri et al. (2008) and Zgorelec (2009) grouped plant species according to their ECs uptake capacities related to trace elements and sensitivity to trace element contamination as follows:

high-accumulator plants EC 1-10

medium-accumulator plants EC 0.1-1

low-accumulator plants EC 0.01-0.1

nonaccumulator plants $\mathrm{EC}<0.01$

The sensitivity or tolerance of plants to excess trace elements depends on plant species and their genotypes. Even among crops, sensitivity varies widely (Adriano, 2001). Excluders are tolerant to high-trace elements concentrations and their tolerance is achieved by preventing the absorption and translocation of toxic elements to aboveground biomass. However, the observed concentrations in the root are lower than those in the soil. These species have low potential for metal extraction, and EC value is less than one (Lasat, 1999). They are insensitive to trace elements over a wide range of concentrations, and a common example is various grass species. Indicators are plant species sensitive to trace elements and consequently certain symptoms can be manifested. Such plants are not tolerant to high concentrations of trace elements, and examples are grain and cereal crops (Adriano, 2001). Accumulators are plants which accumulate trace elements in various concentrations, however, in concentrations which are still lower than in case of hyperaccumulators. Hyperaccumulation is a specific characteristic inherent in certain species. The majority of hyperaccumulators are endemic plants which grow in soils rich in trace elements and behave like strict metallophytes (Baker \& Brooks, 1989), where certain facultative metallophytes can survive in soils poor in the trace elements (Rascio \& Navari-Izzo, 2011). These plants have developed special mechanisms for element uptake and tolerance to high concentrations. The mechanisms are genetically conditioned because the plant tissues do not manifest toxicity symptoms typical in plants due to high element concentrations. For successful hyperaccumulation the concentrations of the trace elements in the above-ground biomass have to be extremely higher compared to their content in the soil (Pulford \& Watson, 2003). The negative aspect of hyperaccumulators is low biomass yield.

\subsection{Phytostabilization of Arable Land Contaminated with Trace Elements}

Phytostabilization uses plants to reduce contaminated soil material movement via water or wind. The approach is commonly used in combination with soil amendments to reduce contaminant bioavailability and to assist plant growth. 
The term "bioavailability" is defined as the fraction of an element in soil which is available for absorption by humans, animals, or plants. In the processes of in situ inactivation or chemical stabilization the appropriate soil amendments are used for immobilization of contaminants in soil (Attanayake et al., 2014; Berti \& Cunningham, 1997; Brown et al., 2003; Defoe et al., 2014; Hettiarachchi et al., 2000). Contaminant immobilization is achieved through enhanced sorption in soil, absorption and accumulation in roots, adsorption to roots or precipitation within the root zone, and physical stabilization of soils (USEPA, 2000). Phytostabilization assisted with soil amendments can also support re-establishment of vegetation at contaminated sites lacking native grasses because of high concentrations of phytotoxic trace elements or poor soil characteristics, i.e., low $\mathrm{pH}$ and poor agrichemical and physical characteristics (Gudichuttu, 2014; Solís-Dominguez et al., 2012; Tordoff et al., 2000; Wijesekara et al., 2016). Phytostabilization is recommended when other remediation approaches are not feasible due to extended contaminated area. It is also useful in case of limited funds for another remediation technique. The advantages of phytostabilization are low cost, simple implementation, and aesthetic aspects (Berti \& Cunningham, 2000). The disadvantages are as follows: needs a long period (usually $30-40$ years) for restoration of the certain area, problems connected with disposal of contaminated biomass, limited development of root system, seasonal and climate dependence.

There are two types of plants suitable for a phytostabilization process. One group is formed by plants tolerant to high concentrations of contaminants, i.e., trace element excluders. Another group is represented by species with highly developed root systems that can immobilize contaminated substances through uptake, precipitation, or reduction. In this case rather often relevant contaminants are concentrated in the roots and only a small portion of contaminants can move to the aboveground part of the plant.

Careful selection of plant species is the determining factor for the success of phytostabilization. Plant characteristics and soil properties are both important for proper selection of the most suitable phytoagent. Native species which can survive in targeted contaminated soil are made a preferred choice in many phytostabilization processes (Solís-Dominguez et al., 2012). In addition, the plants appropriate for phytostabilization are grasses and fast-growing plants which can provide sufficient coverage with developed root systems to stabilize trace elements. Selected plants should be simple for further maintenance after establishment.

\subsection{Bioenergy Crops and Phytostabilization Options}

Bioenergy crops are promising candidates for phytostabilization of soils contaminated with trace elements due to their good ability to grow in contaminated and marginal soils (Pidlisnyuk et al., 2014). Below the main energy 
crops proposed for application in phytoremediation process are characterized. It should be noted here that for the same energy crop, different results have been observed. Differential response is due to multiple reasons, such as soil type, soil amount (for example, small pot studies with insufficient amount of soil), nature of soil contamination (field contaminated versus trace element spiked soils, aged versus not aged, or fresh), and cleaning methods employed for plant materials (i.e., inability to remove surface contaminations).

Arundo donax L. (Giant reed, Figure 2.2) is a perennial, tall, and upright grass with highly efficient $\mathrm{C}_{3}$ photosynthesis. It belongs to the Poaceae family. The origin of Giant reed is not yet accurately defined; however, it is believed to be native from Asia or the Mediterranean basin. The plant is tolerant to

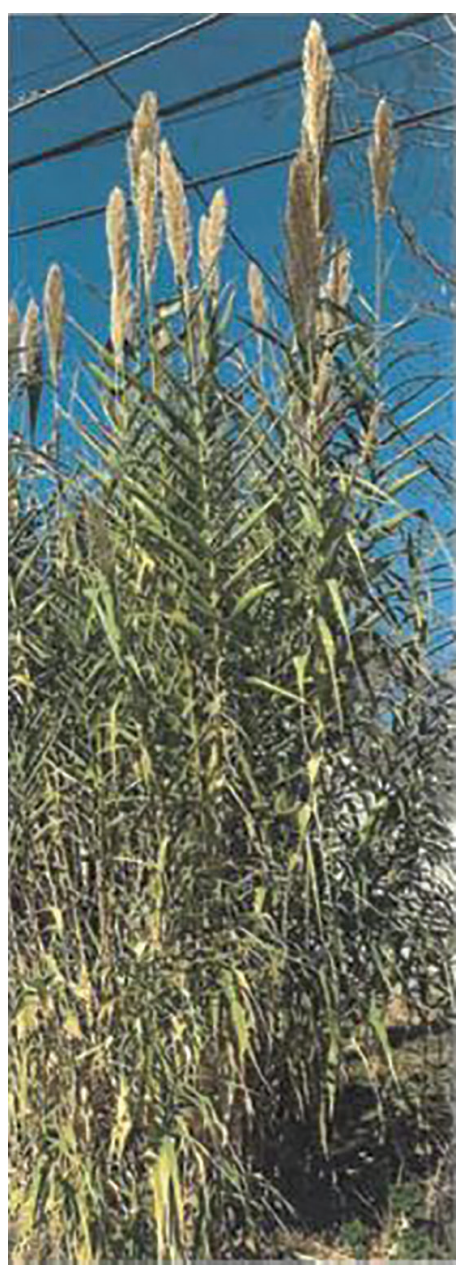

FIGURE 2.2

Arundo donax, Manhattan, KS Nov 2020. Photo by Lawrence Davis. 
unsuitable growing conditions, yet showing best growth in areas with good access to water (Angelini et al., 2005). Giant reed is cultivated well in moderate, subtropical, and tropical areas of both hemispheres (Herrera \& Dudley, 2003). It grows between 6 and $8 \mathrm{~m}$ high, while in ideal conditions the height can exceed $10 \mathrm{~m}$. It is a promising crop for energy production in the Mediterranean climate in Europe and Africa. The advantage is that the crop is adapted to long drying periods (Jeguirim \& Trouvé, 2009; Zema et al., 2012). Plantings can last 12-15 years and may annually produce up to $60 \mathrm{t}$ of dry biomass ha $^{-1}$ in Central and Northern Italy (Angelini et al., 2005; Pilu et al., 2013). A considerable amount of research is reported in Table 2.2 about phytoremediation potential of $A$. donax in a variety of contaminated soils; however, results are mixed.

Panicum virgatum L. (Switchgrass) (Figure 2.3) is an upright, coarse, perennial $\mathrm{C}_{4}$ grass. It belongs to the Poaceae family and originates in North America and Canada. The plant can be produced over an extensive geographic range, and the annual harvested biomass is up to $25 \mathrm{t}$ of dry matter ha ${ }^{-1}$ (Parrish et al., 2012) while stem can grow up to $2.7 \mathrm{~m}$. Switchgrass develops well in marginal soils and shows good results in both fine and coarse textured soils (Rinehart, 2006). The recommended seeding rate is 200-400 germinating seeds $\mathrm{m}^{-2}$. Usually, the amount of seeds for one ha varies from 4 to $10 \mathrm{~kg} \mathrm{ha}^{-1}$ (Moser \& Vogel, 1995; Teel, 2003; Vassey et al., 1985; Vogel, 1987, 2000; Wolf \& Fiske, 2009). Currently cultivation of switchgrass uses mainly hybrids. Some studies with trace elements are reported in Table 2.3.

\section{TABLE 2.2}

Phytoremediation Potential of Arundo donax L. to Different Trace Elements

\begin{tabular}{|c|c|c|}
\hline Trace Element & Phytoremediation Potential & Reference \\
\hline $\mathrm{Cd}$ & $\begin{array}{l}\text { Rhizofiltration in hydroponics } \\
\text { Phytoextraction } \\
\text { Uptake potential from the } \\
\text { media }\end{array}$ & $\begin{array}{l}\text { Dürešová et al. (2014); Sagehashi et al. (2011) } \\
\text { Barbafieri et al. (2011); Chierchia, (2011); } \\
\text { Sabeen et al. (2013); Yang et al. (2012) } \\
\text { Papazoglou et al. (2005); Papazoglou et al. } \\
\text { (2007) }\end{array}$ \\
\hline $\mathrm{Cr}$ & Accumulator & Fiorentino et al. (2013); Kausar et al. (2012) \\
\hline $\mathrm{Cu}$ & $\begin{array}{l}\text { Phytoextraction } \\
\text { Rhizofiltration }\end{array}$ & $\begin{array}{l}\text { Chierchia (2011); Elhawat et al. (2014) } \\
\text { Bonanno (2012) }\end{array}$ \\
\hline $\mathrm{Hg}$ & $\begin{array}{l}\text { Uptakes and accumulates } \\
\mathrm{Hg} \text { in roots }\end{array}$ & Bonanno (2012) \\
\hline $\mathrm{Ni}$ & $\begin{array}{l}\text { Uptake potential from the } \\
\text { media }\end{array}$ & $\begin{array}{l}\text { Bonanno (2012); Papazoglou et al. (2005); } \\
\text { Papazoglou et al. (2007) }\end{array}$ \\
\hline $\mathrm{Pb}$ & $\begin{array}{l}\text { Not efficient in removing } \\
\mathrm{Pb} \text { from the media } \\
\text { Certain genotypes have } \\
\text { phytoextraction potential; } \\
\text { others are excluders }\end{array}$ & $\begin{array}{l}\text { Barbafieri et al. (2011); Bonanno (2012) } \\
\text { Sidella (2014) }\end{array}$ \\
\hline $\mathrm{Zn}$ & $\begin{array}{l}\text { Phytoextraction in } \\
\text { hydroponics }\end{array}$ & Dürešová et al. (2014) \\
\hline
\end{tabular}




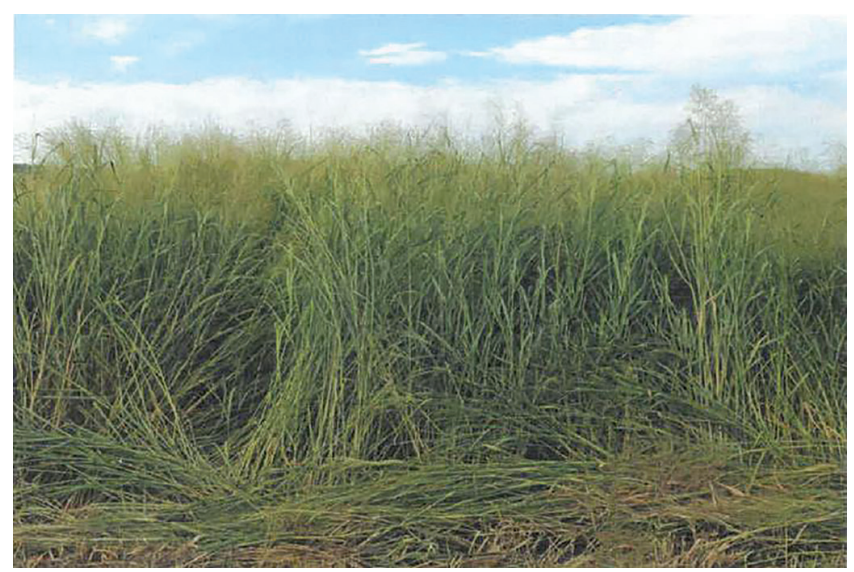

FIGURE 2.3

Switchgrass, (Panicum virgatum) courtesy of Professor John Dolman, K-State.

TABLE 2.3

Phytoremediation Potential of Panicum virgatum L. to Different Trace Elements

\begin{tabular}{lll}
\hline Trace Element & Phytoremediation Potential & \multicolumn{1}{c}{ References } \\
\hline $\mathrm{Cd}$ & Rhizofiltration & Abe et al. (2008); Chen et al. \\
& $\begin{array}{l}\text { Phytoextraction } \\
\text { Accumulator }\end{array}$ & (2008); Sankaran \& Ebbs (2007) \\
& & Gerst (2014); Juang \& Lee (2010) \\
& Chen et al. (2012) \\
& Phytoextraction in hydroponics & Chen et al. (2012) \\
$\mathrm{Cr}$ & Potential remediator & Shahandeh \& Hossner (2000) \\
& Rhizoextraction & Li et al. (2011) \\
$\mathrm{Hg}$ & Not efficient & Gerst (2014) \\
$\mathrm{Pb}$ & Excluder & Gleeson (2007) \\
& Favorable for phytoremediation & Johnson (2014) \\
& Not efficient as accumulator & Żurek et al. (2013) \\
$\mathrm{Zn}$ & Accumulator & Chen et al. (2012) \\
& Favorable for phytostabilization & \\
\hline
\end{tabular}

Pennisetum purpureum Schum. (Napier grass or Elephant grass) is a dense rhizomatous perennial $\mathrm{C}_{4}$ grass which is often crossed with P. americanum to obtain a hybrid with better properties (Figure 2.4). It belongs to the Poaceae family and originates from sub-Saharan Africa; currently, it is widespread in tropical and subtropical regions. This species prefers areas with high precipitation; however, it also tolerates dry conditions due to a well-developed vigorous root system. The best growth is reported for deep, fertile loams, although it grows well on more marginal lands. P. purpureum is an aggressive grass able to grow rapidly, colonize new areas, and form dense thickets; moreover, the species is recognized globally as a very invasive grass. Pennisetum purpureum 


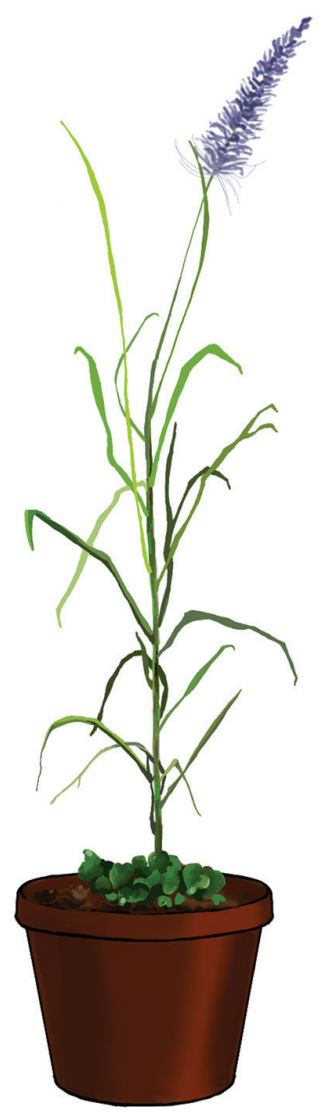

FIGURE 2.4

Pennisetum purpureum Schum (Elephant grass).

grows forming thick clumps up to $1 \mathrm{~m}$ in diameter, with stems branched above, reaching 4-7 m height. Leaf length and width are around $100-120 \mathrm{~cm}$ and 1-5 cm, respectively (CABI, 2014). This plant can be used as a source for cellulosic bioenergy, fodder, cover material, bedding, and paper (Adekalu et al., 2007; Kabi et al., 2005). Positive results were recorded when it was used for treatment of waste sludge (Dhulap \& Patil, 2014) and soil contaminated by hydrocarbons (Ayotamuno et al., 2006). Phytoremediation potentials of elephant grass for different trace elements are reported in Table 2.4.

Sida hermaphrodita L. Rusby (Virginia mallow) is a $\mathrm{C}_{4}$, honey plant species (Figure 2.5) which belongs to Malvaceae family (mallows); it originated in North America. During the 1930s the plant was introduced to former USSR, and currently it can be found in all parts of Europe. Virginia Mallow is tolerant to extreme types of continental climate and can survive in cold conditions 


\section{TABLE 2.4}

Phytoremediation Potential of Pennisetum purpureum Schum. to Different Trace Elements

\begin{tabular}{lll}
\hline Trace Element & Phytoremediation Potential & \multicolumn{1}{c}{ References } \\
\hline $\mathrm{Cd}$ & Rhizofiltration & Lotfy et al. (2012) \\
& Phytoextraction & Abdel-Salam (2012); Zhang et al. (2010) \\
& Accumulator & Ogunkunle et al. (2014) \\
$\mathrm{Cr}$ & Excluder & Lotfy \& Mostafa (2014) \\
& Accumulator in humid & Ogunkunle et al. (2014) \\
& conditions & \\
$\mathrm{Cu}$ & Excluder & Ogunkunle et al. (2014); Yang et al. (2010) \\
$\mathrm{Pb}$ & Excluder & Xia (2004); Yang et al. (2010) \\
& Accumulator & Ogunkunle et al. (2014) \\
$\mathrm{Zn}$ & Excluder & Ogunkunle et al. (2014); Zhang et al. (2010) \\
\hline
\end{tabular}

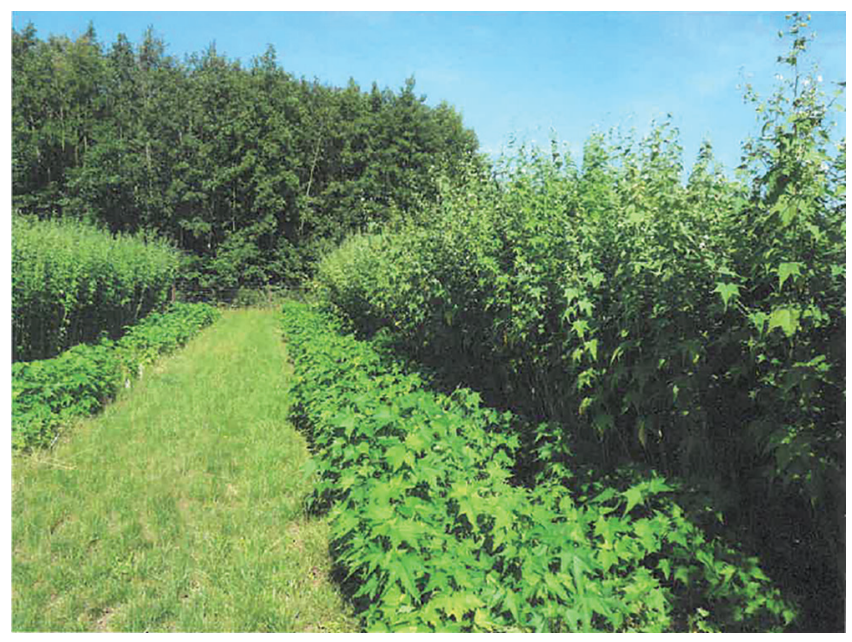

FIGURE 2.5

Sida hermaphrodita a perennial dicot used for forage, or biomass production. With two harvests per year it can serve for biogas production with a total annual harvest exceeding $26 \mathrm{Mg} / \mathrm{ha}$. This photo, courtesy of Professor Marek Bury, ZUT, Szczecin, Poland, shows regrowth after a first harvest, alongside the crop maturing with flowers.

(even without snow at temperatures below $-20^{\circ} \mathrm{C}$ ) and dry conditions if the average annual precipitation ranges between 400 and $500 \mathrm{~mm}$. Height in full maturity varies from 1 to $4 \mathrm{~m}$, commonly reaches about $3 \mathrm{~m}$ (Borkowska \& Molas, 2012). Its life span is about 25 years (Kasprzyk et al., 2013), the annual yield ranges from 15 to $20 \mathrm{t}$ of dry matter ha ${ }^{-1}$ when cultivated in clay loam soils (Borkowska, 2007). In case of unfavorable conditions, the cultivation is often provided with the addition of sewage sludge; in this condition yield ranges from 
none to 11 tons of dry matter ha-1 (Borkowska \& Wardzinska, 2003). The welldeveloped root system allows it to efficiently use limited nutrients and water from marginal soils (Borkowska \& Wardzinska, 2003). S. hermaphrodita grows well in stony or sandy soil with high yields, and best growth is reported for moderately humid areas. Hybrids and cultivars are mainly cultivated now because they have higher yields than the original species. The data about phytoremediation potential of Virginia mallow are summarized in Table 2.5.

Sorghum $\times$ drummondii Steud. (Sudan grass) is an annual, warm-season, fast growing plant (Figure 2.6), which belongs to Poaceae family and is a hybrid of S. bicolor and $S$. arundinaceum, and possesses $C_{4}$ photosynthesis. Sudan grass is originally from Southern Egypt and Sudan; in 1909 it was imported to the US where it began to be grown as a fodder species. The crop is widespread in South America, Australia, South Africa, Central and Northern Europe. It shows best growth in areas with average annual precipitation between 600 and $900 \mathrm{~mm}$, nevertheless tolerates drought periods, and can be produced in all soil types (FAO, 2012). Recently S. drummondii has attracted interests due to its ability to remove trace elements from different media (Table 2.6). According to Pivetz (2001) it can absorb and accumulate Co. Application of microbial inoculants improved the remediation process (Shim et al., 2014). Utilization of certain mycorrhizal fungi which form a symbiosis with $S$. $x$ drummondii can increase the accumulation of trace elements from the contaminated soil (Gaur \& Adholeya, 2004).

The Miscanthus genus belongs to the Poaceae (or grasses) family (Figure 2.7). It has $\mathrm{C}_{4}$ photosynthesis with high water and nutrient-use efficiency and cold tolerance (Chung \& Kim, 2012). The genus can be found within high lawns of

TABLE 2.5

Phytoremediation Potential of Sida hermaphrodita L. to Different Trace Elements

\begin{tabular}{|c|c|c|}
\hline Trace Element & $\begin{array}{l}\text { Phytoremediation } \\
\text { Potential }\end{array}$ & References \\
\hline$\overline{\mathrm{Cd}}$ & $\begin{array}{l}\text { Phytoextraction } \\
\text { Rhizofiltration } \\
\text { Potential accumulator }\end{array}$ & $\begin{array}{l}\text { Ociepa (2011) } \\
\text { Antonkiewicz \& Jasiewicz (2002) } \\
\text { Borkowska et al. (2001); Krzywy-Gawrońska (2012) }\end{array}$ \\
\hline $\mathrm{Cr}$ & $\begin{array}{l}\text { Efficiently removes } \mathrm{Cr} \\
\text { from the media }\end{array}$ & Borkowska et al. (2001) \\
\hline $\mathrm{Cu}$ & $\begin{array}{l}\text { Efficiently removes } \mathrm{Cu} \\
\text { from the media } \\
\text { Rhizoextraction }\end{array}$ & $\begin{array}{l}\text { Borkowska et al. (2001) } \\
\text { Antonkiewicz \& Jasiewicz (2002); } \\
\text { Krzywy-Gawrońska (2012) }\end{array}$ \\
\hline $\mathrm{Ni}$ & $\begin{array}{l}\text { Efficient in } \\
\text { phytoextraction } \\
\text { Rhizoextraction }\end{array}$ & $\begin{array}{l}\text { Krzywy-Gawrońska (2012) } \\
\text { Antonkiewicz \& Jasiewicz (2002) }\end{array}$ \\
\hline $\mathrm{Pb}$ & $\begin{array}{l}\text { Phytoextraction } \\
\text { Accumulator }\end{array}$ & $\begin{array}{l}\text { Krzywy-Gawrońska (2012) } \\
\text { Kocoń \& Matyka (2012) }\end{array}$ \\
\hline $\mathrm{Zn}$ & $\begin{array}{l}\text { Phytoextraction } \\
\text { Accumulator }\end{array}$ & $\begin{array}{l}\text { Krzywy-Gawrońska (2012) } \\
\text { Borkowska et al. (2001) }\end{array}$ \\
\hline
\end{tabular}




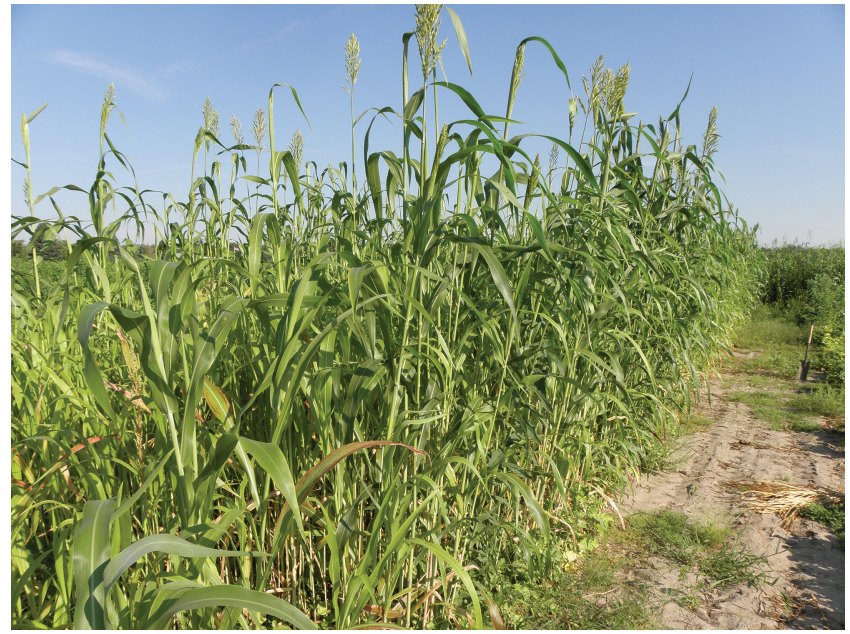

FIGURE 2.6

Sudan-Sorghum forage hybrid at the USDA Plant Materials Center, Ashland Bottoms, Manhattan, KS, August 2013. Photo courtesy of Mark Janzen, Natural Resources Conservation Services, USDA.

\section{TABLE 2.6}

Phytoremediation Potential of Sorghum $x$ drummondii Steud. to Different Trace Elements

\begin{tabular}{|c|c|c|}
\hline $\begin{array}{l}\text { Trace } \\
\text { Element }\end{array}$ & Phytoremediation Potential & References \\
\hline $\mathrm{Cd}$ & $\begin{array}{l}\text { Excluder } \\
\text { Rhizoextraction }\end{array}$ & $\begin{array}{l}\text { Angelova et al. (2011); López-Chuken and } \\
\text { Young (2005); Zwonitzer et al. (2003) } \\
\text { Da-lin et al. (2011) }\end{array}$ \\
\hline $\mathrm{Cu}$ & Excluder & Angelova et al. (2011); Tari et al. (2013) \\
\hline $\mathrm{Pb}$ & $\begin{array}{l}\text { Suitable for phytoremediation } \\
\text { Chemically induced remediation } \\
\text { Excluder }\end{array}$ & $\begin{array}{l}\text { Murányi and Ködöböcz (2008) } \\
\text { Zhuang et al. (2009) } \\
\text { Angelova et al. (2011) }\end{array}$ \\
\hline $\mathrm{Zn}$ & Excluder & Angelova et al. (2011) \\
\hline
\end{tabular}

Eastern Asia, from tropics and subtropics to Pacific islands, warm temperate regions, and subarctic areas. Wide adaptability to various environmental factors makes M. x giganteus a sterile triploid hybrid of M. sinensis and $M$. sacchariflorus, suitable for cultivating in different European and Northern American climatic conditions (Greef \& Deuter, 1993, See Chapter 5 for further information about breeding of various hybrid Miscanthus and different species properties). Plant biomass annual yield ranges from 8 to $45 \mathrm{t}$ dry biomass ha ${ }^{-1}$ (Bilandžija, 2015; Heaton et al., 2008; Lewandowski et al., 2000; Maughan et al., 2012; Miguez et al., 2008) with long sustainable productivity 


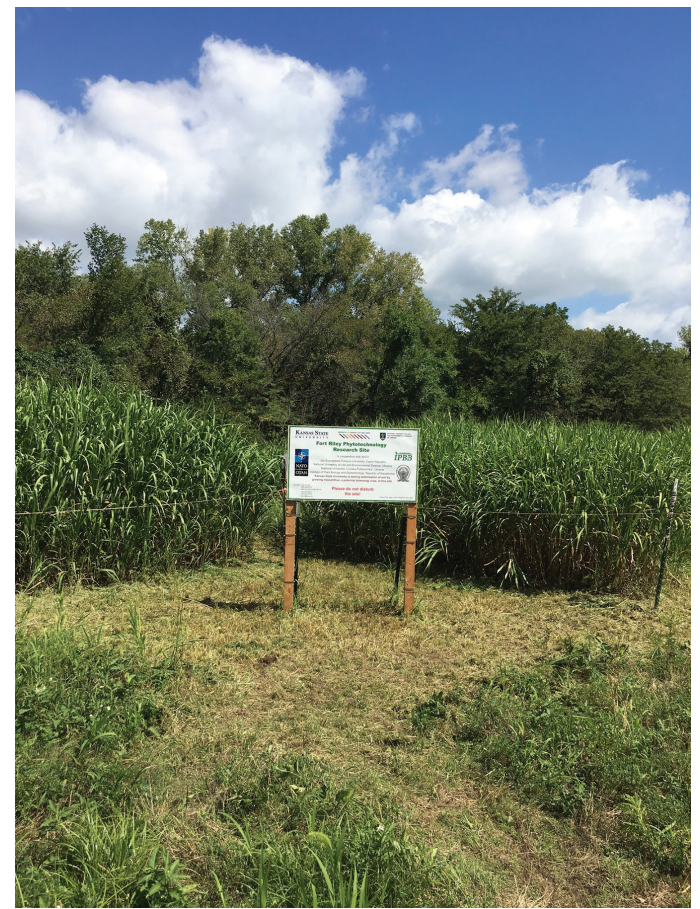

FIGURE 2.7

Miscanthus at Fort Riley, site, KS. USA. (Photo: Zafer Alasmary, Kansas State University, KS, USA.)

after the establishment of up to 20 years, or more. M. x giganteus has a high carbon sequestration capacity as well because of its dense rhizome and root system (Chung \& Kim, 2012). Commonly, the initial planting density per ha is between 10,000 and 13,000 plants. The main characteristics of Miscanthus as a prospective biofuel crop are as follows: exceptional cultivation adaptation in different climatic and pedological conditions, possibility to grow in soils of inferior quality, high dry matter yields, high energy value, exceptional resistance to diseases and pests, and low demand for nutrients. As a natural sterile hybrid, invasive spread is much lower in comparison with some other energy crops (Bilandžija, 2014).

\subsection{M. $\times$ giganteus as an Effective Phytoagent}

Plants have to meet certain requirements for application in phytoremediation of contaminated sites: to be resistant to pests, plant diseases, and contaminants 
of different origin; to be able to grow at the same site long term. M. $\times$ giganteus has all of these properties (Clifton-Brown et al., 2008; Dauber et al., 2010). The plant is among the more promising bioenergy crops due to high yield, water and nutrient use efficiency, and lignocellulose content. Lewandowski et al. (2016) pointed that M. x giganteus has only weak ability to absorb contaminants; therefore, it can be cultivated in contaminated soils while obtaining relatively clean biomass.

The selection of Miscanthus for phytomanagement of different contaminated areas with simultaneous production of alternative energy source is getting popular (Amougou et al., 2011; Dubis et al., 2019; Kołodziej et al., 2016; Kvak et al., 2018; Lewandowski et al., 2005; Matyka \& Kuś, 2016; Roik et al., 2019; Tryboi, 2018). Thus, because Miscanthus covers $15 \%$ of the total bioenergy plant market in some Eastern European countries (Geletukha et al., 2016), can stabilize and accumulate some trace elements, absorb and degrade contaminants of organic origin, facilitate carbon deposition, and improve physico-chemical properties of soil, this plant may be successfully applied for restoration of postmining (Kharytonov et al., 2019; Nurzhanova et al., 2019; Pidlisnyuk et al., 2020a, b) and postmilitary (Alasmary, 2020; Pidlisnyuk et al., 2018, 2019) sites (Table 2.7). Miscanthus brings ecological benefits with economic profit due to using biomass for energy and bioproducts.

\subsubsection{Miscanthus Tolerance to Metals and Removal Capacity}

Miscanthus' ability to grow in soils contaminated by trace elements (Alasmary, 2020; Pidlisnyuk et al., 2019; Wilkins, 1997) is determined by the following factors (Wang et al., 2020):

\section{TABLE 2.7}

Phytoremediation Potential of M. x giganteus to Different Trace Elements

\begin{tabular}{lll}
\hline Trace Element & Phytoremediation Potential & \multicolumn{1}{c}{ Reference } \\
\hline $\mathrm{Cd}$ & Rhizoextraction & Arduini et al. (2006) \\
& Excluder & Fernando and Oliveira (2004) \\
& Phytostabilization & Nsanganwimana et al. (2015) \\
$\mathrm{Cr}$ & Rhizoextraction & Arduini et al. (2006) \\
& Excluder & Fernando and Oliveira (2004) \\
$\mathrm{Cu}$ & Excluder & Fernando and Oliveira (2004) \\
$\mathrm{Hg}$ & Excluder & Fernando and Oliveira (2004) \\
$\mathrm{Ni}$ & Excluder & Fernando and Oliveira (2004) \\
$\mathrm{Pb}$ & Excluder & Pavel et al. (2014) \\
& Excluder & Fernando and Oliveira (2004) \\
& Phytostabilization & Nsanganwimana et al. (2015) \\
$\mathrm{Zn}$ & Accumulator & Pogrzeba et al. (2013) \\
& Excluder & Fernando and Oliveira (2004) \\
& Phytostabilization & Nsanganwimana et al. (2015) \\
\hline
\end{tabular}


a. Miscanthus root systems are large and well-developed, and plant metabolism is vigorous. Also, carbon-containing compounds released by plant roots supply the microorganisms located in rhizosphere (Rhizobacteria) with nutrients and organic acids (Hromádko et al., 2014; Zgorelec et al., 2020). Such acids can suppress trace element toxicity. Guo et al. (2017) reported that under Cd stress $M$. sacchariflorus roots secreted malate which mitigated $\mathrm{Cd}$ toxicity for the plant, by reducing its absorption.

b. Antioxidant and photosynthetic activities of Miscanthus are well developed. The antioxidant defense system plays a crucial role in plant stress response. Along with the ability to mitigate stress-induced disturbances, it can serve as an indicator of trace element toxicity-induced stress. An increase of malondialdehyde content reflects Cr stress (Jiang et al., 2018). Significant increases in chlorophyll content, superoxide dismutase, and peroxidase activities are observed in $M$. floridulus and M. sacchariflorus growing in soil slightly contaminated by $\mathrm{Pb}, \mathrm{Zn}$, or Cd (Zhang et al., 2015). M. x giganteus behavior was similar under $\mathrm{Pb}$ and Zn stresses (Nurzhanova et al., 2019).

c. The Miscanthus rhizosphere contains many microbial colonies that participate in plant-soil interaction (Wang et al., 2020). Schmidt et al. (2018) reported that plant inoculation with bacteria and fungi isolated from different Miscanthus species' rhizospheres improved plant growth. Firmin et al. (2015) obtained the same result after inoculating M. x giganteus by Funneliformis mosseae. Inoculation of Miscanthus rhizomes with plant growth promoting bacteria increased the biomass by $\sim 77 \%$ after first vegetation season in postmining soil contaminated by trace elements (Pidlisnyuk et al., 2020a; Pranaw et al., 2020).

\subsubsection{Changes in Soil Parameters Induced by Miscanthus Phytoremediation}

Miscanthus planting in contaminated soils can increase soil carbon content, enhance aggregate stability, and improve water-holding capacity. The improving effect of the plant on soil physiochemical properties is mainly attributed to decomposition of underground organs and litter of root residuals in soil (Wang et al., 2020). McCalmont et al. (2015) showed that the decomposition of litter and underground organs of Miscanthus provides a large amount of organic carbon to soil, which increases soil organic matter, promotes soil nutrient cycling, improves the texture, structure, and waterholding soil capacity, and reduces soil nutrient loss.

Miscanthus was cultivated in marginal soil with the application of soil amendments, biochar, and biosolid, that enhanced the abundance of humus and mycorrhizal fungi, and improved soil fertility and hydraulic properties. Biosolids exerted the most pronounced effect (Allami et al., 2019). 
Zhang et al. (2020) applied mixed planting of Miscanthus, Masson pine, and Bamboo for phytoremediation of a mining area. After 3 years of cultivation, the abundance of the mixed vegetation was tremendously higher, and microflora in remediated soil was larger in comparison with the control one. Miscanthus significantly reduces the release of $\mathrm{NO}_{x}$ and increases the absorbing capacity for $\mathrm{CH}_{4}$. The net release of greenhouse gases was reduced to an extent of $4.08 \mathrm{t} \mathrm{CO}_{2}$-eq per hectare per year (Mi et al., 2018).

In the long run during Miscanthus cultivation, soil carbon sequestration could be significantly different (Holder et al., 2019). During one life cycle (15 years), Miscanthus may release twice the amount of greenhouse gas in comparison to permanent grassland. Compared to the grassland soils, the surface soils of Miscanthus fields tend to have a risk of acidification due to higher concentrations of $\mathrm{P}$ and $\mathrm{K}$ (Hu et al., 2018). Therefore, when evaluating the impacts of Miscanthus cultivation, soil characteristics and soil organic carbon stability should be taken into consideration in the long-term perspective.

\subsection{Miscanthus Phytotechnology in Action}

\subsubsection{M. × giganteus Application for Phytoremediation of Trace Elements' Contaminated Mining Soil, Tekeli, Kazakhstan}

The research soil was sampled around the Tekeli Mining and Processing Complex of "Kazzinc", Kazakhstan. Soil was contaminated by trace elements in concentrations that exceeded the maximum permissible levels in Kazakhstan, i.e., the exceeding for Pb was in 29 times, As - 5 times, Zn 11 times, $\mathrm{Sr}-22$ times, $\mathrm{Cu}-13$ times. Research soil belonged to saline and sandy types; its $\mathrm{pH}$ (water) ranged from 8.3 to 9.9 (Nurzhanova et al., 2019).

The experiment lasted two vegetation seasons. During the experiment soil and $M$. x giganteus tissues (root, stems, and leaves) were analyzed for the content of eleven trace elements: $\mathrm{As}, \mathrm{Pb}, \mathrm{Zn}, \mathrm{Co}, \mathrm{Ni}, \mathrm{Cr}, \mathrm{Cu}, \mathrm{Sr}, \mathrm{Mn}, \mathrm{V}$, and $\mathrm{U}$. These elements mainly accumulated in the $M$. $\times$ giganteus root system. Accumulation of $\mathrm{Zn}$, Sr, and Mn was higher than others (Figure 2.8). M. x giganteus behaved as an excluder (BCF and TLF values are lower than 1) preferentially accumulating the observed trace elements in roots; however, in relation to $\mathrm{Mn}, \mathrm{Sr}$, and $\mathrm{Zn}$ the plant acted as extractor (BCF $<1$ and TLF $\geq 1$ ) (Nurzhanova et al., 2019).

\subsubsection{M. $\times$ giganteus Application for Phytoremediation of Post- Industrial Soil Contaminated with Trace Elements, Bakar, Croatia}

This experiment was based on monitoring of $M$. $\times$ giganteus phytoremediation potential in relation to post-industrial soil of Rijeka-Bakar industrial zone, Croatia, which was contaminated by different trace elements (Pidlisnyuk et al., 2020b). The biomass parameters and concentrations of $\mathrm{Ti}, \mathrm{Mn}, \mathrm{Fe}, \mathrm{Cu}$, 


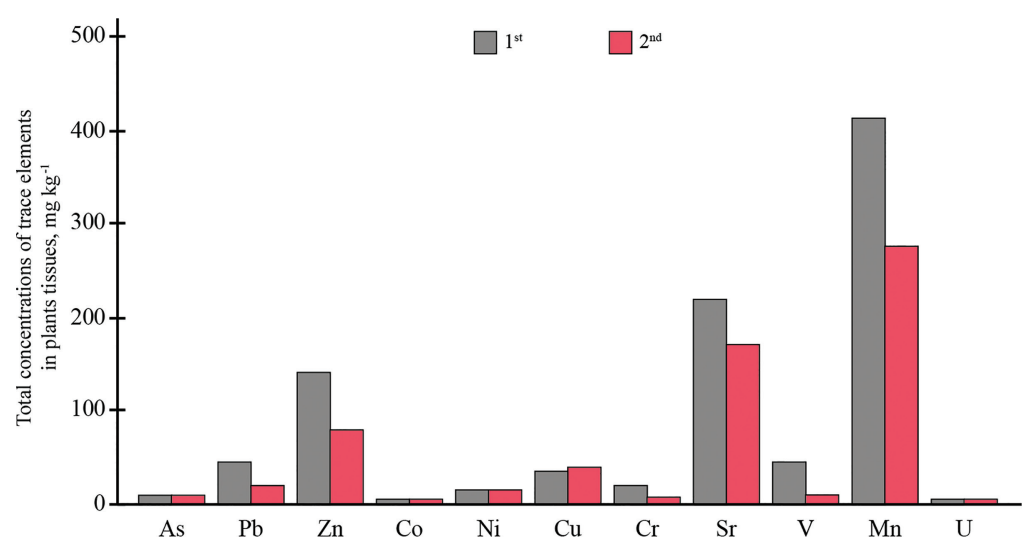

FIGURE 2.8

Element accumulations in $M$. x giganteus tissues during two vegetation seasons

$\mathrm{Zn}, \mathrm{As}, \mathrm{Sr}$, and Mo in stems, leaves, and roots were analyzed in each of three vegetation seasons at harvest. The following categories were used as features affecting the phytoremediation process: the difference in trace elements distribution along the plant; trace element concentrations in the researched soil; different regimes of trace elements absorption by roots and transmigration to plant organs; and vegetation season. Results of the statistical analysis (Pidlisnyuk et al., 2020b) showed that the main factor was trace element organ distribution which was essential for $\mathrm{Ti}, \mathrm{Fe}$, and $\mathrm{Cu}$. The difference in trace element concentration in soil significantly correlated with $\mathrm{Zn}$ and Mo was essentially lower with $\mathrm{As}$, $\mathrm{Sr}$, and $\mathrm{Mn}$, while for $\mathrm{Ti}$ and $\mathrm{Cu}$ correlation was not detected. The impact of the combined effect of two factors (trace elements organ distribution and difference in trace element concentration in soil) was detected for two elements: more prominent for $\mathrm{Cu}$ and smaller for Ti.

The plants organs (variable "Zone") mainly affect the trace elements concentration variations, i.e., accumulation in specific plants part: it was the most essential for $\mathrm{Ti}, \mathrm{Fe}$, and $\mathrm{Cu}$ and the smallest for $\mathrm{Mn}$. The second factor (trace elements concentration in soil - variable "Experiment") was the most essential for $\mathrm{Zn}$ and Mo; however, much less for As, Sr, and Mn; limited for Fe; and was not observed for $\mathrm{Ti}$ and $\mathrm{Cu}$. The combined effect of the above two factors was detected for two elements: higher for $\mathrm{Cu}$ and lower for Ti (Figure 2.9).

\subsubsection{Field Study Results, Fort Riley, Kansas, USA}

In a field study established in 2016, on an US Army reservation in Fort Riley, $\mathrm{KS}$, Miscanthus was planted in an area with soil total $\mathrm{Pb}$ concentration ranging from 900 to $1500 \mathrm{mg} \mathrm{kg}^{-1}$ and near-neutral soil $\mathrm{pH}$. Five treatments were evaluated: (i) control without tillage with existing vegetation; (ii) no-tillage, no additional amendments planted with Miscanthus; (iii) tilled soil, no additional amendments planted with Miscanthus; (iv) tilled soil amended with triple 


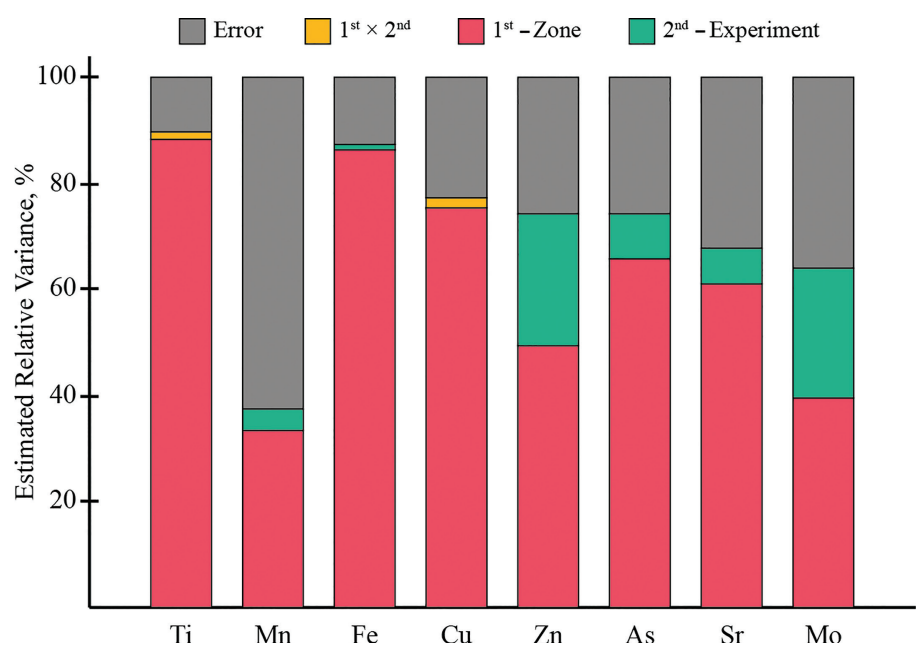

FIGURE 2.9

The components of the element concentration variation (after Box-Cox transformation) depended on plant organs (variable 1 - "Zone"), experiment treatment (variable 2 - "Experiment"), and its interaction $(1 * 2)$ (with vegetation duration as a covariate). Notes: Zone - the effect of the plant organs (roots, leaves, stems), experiment - the effect of the experiment treatments (level 1-5), $1 * 2$ - the interaction effects of the Zone and Experiment.

superphosphate (at 5:3 Pb:P molar ratio) planted with Miscanthus; and (v) tilled soil amended with organic P source (class B biosolids applied at $45 \mathrm{Mg}$ ha $^{-1}$ air-dry weight basis) planted with Miscanthus. Results from 2016 to 2018 showed that one-time addition of soil amendments to Pb-contaminated soil supports establishing and stabilizing Miscanthus, increasing biomass yield as well as reducing phytoavailability and bioaccessibility of $\mathrm{Pb}$ (as measured by physiological-based extraction test procedure developed by Ruby et al. (1996) and modified by Medlin (1997)). Moreover, biosolids-treated plots showed improved soil enzyme activities, organic carbon, and microbial biomass (Alasmary et al., 2020). X-ray absorption spectroscopy results indicated pyromorphite, $\mathrm{Pb}$ associated with Fe minerals, and $\mathrm{Pb}$ adsorbed to humic acid were the dominant $\mathrm{Pb}$ species in P-amended and nonamended soils (Unpublished data, Alasmary and Hettiarachchi). The results suggest that Miscanthus can be grown successfully in $\mathrm{Pb}$-contaminated military site soils combined with soil amendments, while minimizing the associated environmental risks.

\subsection{Conclusions}

Using energy crops in phytostabilization of soils contaminated with trace elements is one of the green technologies that provides ecological, economic, and social solutions for contaminated areas, while meeting energy needs and 
mitigating climate change. The classification of plant species into corresponding groups (hyperaccumulator, accumulator, indicator, excluder) is complex as different conditions (soil type, $\mathrm{pH}$, climate, location, media, plant properties, choice of cultivars, etc.) can influence plant uptake of trace elements and there is no universal approach. Miscanthus proved its ability to grow and to remediate soils contaminated by trace elements with sufficient biomass yield. Besides the obvious advantages of Miscanthus as a phytoremediation agent, its cultivation on the marginal and slightly contaminated lands can improve the soil biological parameters, such as basal respiration, microbial biomass carbon, fluorescein diacetate hydrolytic activity, other enzymatic activities, and simultaneously prevent soil and water erosion. The application of Miscanthus in phytomanagement can improve soil health and help to supply biomass for utilization to obtain energy or bioproducts. Utilization of Miscanthus for phytomanagement of differently contaminated soils is a prospective green technology with potential widespread commercial feedback.

\section{References}

Abdel-Salam, M. (2012). Chemical and phyto-remediation of clayey and sandy textured soils polluted with cadmium. American-Eurasian Journal of Agricultural $\mathcal{E}$ Environmental Sciences, 12(6), 689-693. https://doi.org/10.5829/idosi. aejaes.2012.12.06.1801.

Abe, T., Fukami, M., \& Ogasawara, M. (2008). Cadmium accumulation in the shoots and roots of 93 weed species. Soil Science $\mathcal{E}$ Plant Nutrition, 54(4), 566-573. https://doi.org/10.1111/j.1747-0765.2008.00288.x.

Adekalu, K. O., Olorunfemi, I. A., \& Osunbitan, J. A. (2007). Grass mulching effect on infiltration, surface runoff and soil loss of three agricultural soils in Nigeria. Bioresource Technology, 98(4), 912-917. https://doi.org/10.1016/j. biortech.2006.02.044.

Adriano, D. (2001). Bioavailability of trace metals. In Domy C. Adriano (Ed.), Trace Elements in the Terrestrial Environment (2nd Edition, pp. 61-89), SpringerVerlag, New York.

Alasmary, Z. (2020). Laboratory- to field-scale investigations to evaluate phosphate amendments and Miscanthus for phytostabilization of lead-contaminated military sites [PhD, Kansas State University]. https://krex.k-state.edu/dspace/ handle/2097/40676.

Alasmary, Z., Todd, T., Hettiarachchi, G. M., Stefanovska, T., Pidlisnyuk, V., Roozeboom, K., Erickson, L., Davis, L., \& Zhukov, O. (2020). Effect of soil treatments and amendments on the nematode community under Miscanthus growing in a lead contaminated military site. Agronomy, 10(11), 1727. https:// doi.org/10.3390/agronomy10111727.

Allami, M., Oustriere, N., Gonzales, E., \& Burken, J. G. (2019). Amendment-assisted revegetation of mine tailings: Improvement of tailings quality and biomass production. International Journal of Phytoremediation, 21(5), 425-434. https://doi.org/ 10.1080/15226514.2018.1537249. 
Amougou, N., Bertrand, I., Machet, J.-M., \& Recous, S. (2011). Quality and decomposition in soil of rhizome, root and senescent leaf from Miscanthus $\times$ giganteus, as affected by harvest date and N fertilization. Plant and Soil, 338(1), 83-97. https:// doi.org/10.1007/s11104-010-0443-x.

Angelini, L. G., Ceccarini, L., \& Bonari, E. (2005). Biomass yield and energy balance of giant reed (Arundo donax L.) cropped in central Italy as related to different management practices. European Journal of Agronomy, 22(4), 375-389. https://doi. org/10.1016/j.eja.2004.05.004.

Angelova, V., Ivanova, R., Delibaltova, V., \& Ivanov, K. (2011). Use of sorghum crops for in situ phytoremediation of polluted soils. Journal of Agricultural Science and Technology. A, 1(5), 693-702.

Antonkiewicz, J., \& Jasiewicz, C. (2002). The use of plants accumulating heavy metals for detoxification of chemically polluted soils. Electronic Journal of Polish Agricultural Universities, 5(1), 121-143.

Arduini, I., Ercoli, L., Mariotti, M., \& Masoni, A. (2006). Response of miscanthus to toxic cadmium applications during the period of maximum growth. Environmental and Experimental Botany, 55(1), 29-40. https://doi.org/10.1016/j. envexpbot.2004.09.009.

Attanayake, C. P., Hettiarachchi, G. M., Harms, A., Presley, D., Martin, S., \& Pierzynski, G. M. (2014). Field evaluations on soil plant transfer of lead from an urban garden soil. Journal of Environmental Quality, 43(2), 475-487. https://doi.org/10.2134/ jeq2013.07.0273.

Ayotamuno, J. M., Kogbara, R. B., \& Egwuenum, P. N. (2006). Comparison of corn and elephant grass in the phytoremediation of a petroleum-hydrocarboncontaminated agricultural soil in Port Harcourt, Nigeria. Journal of Food Agriculture and Environment, 4(3/4), 218.

Baker, A. J. M. (1981). Accumulators and excluders strategies in the response of plants to heavy metals. Journal of Plant Nutrition, 3(1-4), 643-654. https://doi. org/10.1080/01904168109362867.

Baker, A. J., \& Brooks, R. (1989). Terrestrial higher plants which hyperaccumulate metallic elements. A review of their distribution, ecology and phytochemistry. Biorecovery, 1(2), 81-126.

Barbafieri, M., Dadea, C., Tassi, E., Bretzel, F., \& Fanfani, L. (2011). Uptake of heavy metals by native species growing in a mining area in Sardinia, Italy: Discovering native flora for phytoremediation. International Journal of Phytoremediation, 13(10), 985-997. https://doi.org/10.1080/15226514.2010.549858.

Berti, W. R., \& Cunningham, S. D. (1997). In-place inactivation of $\mathrm{Pb}$ in Pb-contaminated soils. Environmental Science E Technology, 31(5), 1359-1364. https://doi.org/10.1021/es960577+.

Berti, W. R., \& Cunningham, S. D. (2000). Phytostabilization of metals. In Ilya Raskin \& Burt D. Ensley (Eds.), Phytoremediation of Toxic Metals: Using Plants to Clean up the Environment (pp. 71-88), Wiley, New York.

Bilandžija, N. (2014). Perspective and potential use of Miscanthus $\times$ giganteus culture in Croatia [Perspektiva i potencijal korištenja kulture Miscanthus $\times$ giganteus $u$ Republici Hrvatskoj]. Environmental Engineering - Inženjerstvo okoliša, 1(2), 81-87. https://hrcak.srce.hr/index.php?show=clanak\&id_clanak_jezik=195970.

Bilandžija, N. (2015). The potential of Miscanthus $x$ giganteus species as an energy crop in different technological and environmental conditions [Potencijal vrste Miscanthus $\times$ giganteus kao energetske kulture u različitim tehnološkim i agroekološkim uvjetima] [PhD, University of Zagreb]. 
Bonanno, G. (2012). Arundo donax as a potential biomonitor of trace element contamination in water and sediment. Ecotoxicology and Environmental Safety, 80, 20-27. https://doi.org/10.1016/j.ecoenv.2012.02.005.

Borkowska, H. (2007). Yields of Virginia fanpetals and willow on good wheat soil complex. Fragmenta Agronomica, 2, 41-47.

Borkowska, H., Jackowska, I., Piotrowski, J., Styk, B., Piotrowski, J., \& Styk, B. (2001). Suitability of cultivation of some perennial plant species on sewage sludge. Polish Journal of Environmental Studies, 10(5), 379-382.

Borkowska, H., \& Molas, R. (2012). Two extremely different crops, Salix and Sida, as sources of renewable bioenergy. Biomass and Bioenergy, 36, 234-240. https://doi. org/10.1016/j.biombioe.2011.10.025.

Borkowska, H., \& Wardzinska, K. (2003). Some effects of Sida hermaphrodita R. cultivation on sewage sludge. Polish Journal of Environmental Studies, 12(1), 119-122.

Brown, S., Chaney, R. L., Hallfrisch, J. G., \& Xue, Q. (2003). Effect of biosolids processing on lead bioavailability in an urban soil. Journal of Environmental Quality, 32(1), 100-108. https://doi.org/10.2134/jeq2003.1000.

CABI. (2014). Invasive Species Compendium. Centre for Agriculture and Bioscience International.

Chen, B.-C., Lai, H.-Y., \& Juang, K.-W. (2008). Model evaluation of plant metal content and biomass yield for the phytoextraction of heavy metals by switchgrass. Ecotoxicology and Environmental Safety, 80, 393-400. https://doi.org/10.1016/j. ecoenv.2012.04.011.

Chen, B.-C., Lai, H.-Y., \& Juang, K.-W. (2012). Model evaluation of plant metal content and biomass yield for the phytoextraction of heavy metals by switchgrass. Ecotoxicology and Environmental Safety, 80, 393-400. https://doi.org/10.1016/j. ecoenv.2012.04.011.

Chierchia, A. (2011). L'Arundo donax per la bonifica dei suoli contaminati da metalli pesanti [Master, University of Napoli "Federico II"].

Chung, J.-H., \& Kim, D.-S. (2012). Miscanthus as a potential bioenergy crop in East Asia. Journal of Crop Science and Biotechnology, 15(2), 65-77. https://doi. org/10.1007/s12892-012-0023-0.

Clifton-Brown, J., Chiang, Y.-C., \& Hodkinson, T. R. (2008). Miscanthus: Genetic resources and breeding potential to enhance bioenergy production. In W. Vermerris (Ed.), Genetic Improvement of Bioenergy Crops (pp. 295-308), Springer, New York. https://doi.org/10.1007/978-0-387-70805-8_10.

Conesa, H. M., Evangelou, M. W. H., Robinson, B. H., \& Schulin, R. (2012, January 4). A critical view of current state of phytotechnologies to remediate soils: Still a promising tool? [Review Article]. The Scientific World Journal. https://doi. org/10.1100/2012/173829.

Da-lin, L., Kai-qi, H., Jing-jing, M., Wei-wei, Q., Xiu-ping, W., \& Shu-pan, Z. (2011). Effects of cadmium on the growth and physiological characteristics of sorghum plants. African Journal of Biotechnology, 10(70), 15770-15776. https://doi. org/10.4314/ajb.v10i70.

Dauber, J., Jones, M. B., \& Stout, J. C. (2010). The impact of biomass crop cultivation on temperate biodiversity. GCB Bioenergy, 2(6), 289-309. https://doi. org/10.1111/j.1757-1707.2010.01058.x.

Defoe, P. P., Hettiarachchi, G. M., Benedict, C., \& Martin, S. (2014). Safety of gardening on lead- and arsenic-contaminated urban brownfields. Journal of Environmental Quality, 43(6), 2064-2078. https://doi.org/10.2134/jeq2014.03.0099. 
Dhulap, V., \& Patil, S. (2014). Removal of pollutants from sewage through constructed wetland using Pennisetum purpureium. European Educational Research Journal, 2(1), 543-558.

Dubis, B., Jankowski, K. J., Załuski, D., Bórawski, P., \& Szempliński, W. (2019). Biomass production and energy balance of Miscanthus over a period of 11 years: A case study in a large-scale farm in Poland. GCB Bioenergy, 11(10), 1187-1201. https:// doi.org/10.1111/gcbb.12625.

Dürešová, Z., Šuňovská, A., Horník, M., Pipíška, M., Gubišová, M., Gubiš, J., \& Hostin, S. (2014). Rhizofiltration potential of Arundo donax for cadmium and zinc removal from contaminated wastewater. Chemical Papers, 68(11), 1452-1462. https://doi.org/10.2478/s11696-014-0610-2.

Elhawat, N., Alshaal, T., Domokos-Szabolcsy, É., El-Ramady, H., Márton, L., Czakó, M., Kátai, J., Balogh, P., Sztrik, A., Molnár, M., Popp, J., \& Fári, M. G. (2014). Phytoaccumulation potentials of two biotechnologically propagated ecotypes of Arundo donax in copper-contaminated synthetic wastewater. Environmental Science and Pollution Research, 21(12), 7773-7780. https://doi.org/10.1007/s11356-014-2736-8.

Evangelou, M. W. H., Papazoglou, E. G., Robinson, B. H., \& Schulin, R. (2015). Phytomanagement: Phytoremediation and the production of biomass for economic revenue on contaminated land. In A. A. Ansari, S. S. Gill, R. Gill, G. R. Lanza, \& L. Newman (Eds.), Phytoremediation: Management of Environmental Contaminants (Vol. 1, pp. 115-132). Springer International Publishing, New York. https://doi.org/10.1007/978-3-319-10395-2_9.

FAO. (2012). The Grassland Index. Food and Agriculture Organization. https://web. archive.org/web/20170102172754/http://www.fao.org/ag/AGp/agpc/doc/ gbase/mainmenu.htm

Fernando, A., \& Oliveira, J. (2004). Effects on growth, productivity and biomass quality of Miscanthus x giganteus of soils contaminated with heavy metals [2nd World Conference on Biomass for Energy, Industry and Climate Protection], 10-14 May, 2004, Rome, Italy. https://moodle.fct.unl.pt/pluginfile.php/92027/mod_ resource/content/0/Fernando_e_Oliveira_2004.pdf. 10-14.

Fiorentino, N., Fagnano, M., Adamo, P., Impagliazzo, A., Mori, M., Pepe, O., Ventorino, V., \& Zoina, A. (2013). Assisted phytoextraction of heavy metals: Compost and Trichoderma effects on giant reed (Arundo donax L.) uptake and soil N-cycle microflora. Italian Journal of Agronomy, 8(4), 244-254.

Firmin, S., Labidi, S., Fontaine, J., Laruelle, F., Tisserant, B., Nsanganwimana, F., Pourrut, B., Dalpé, Y., Grandmougin, A., Douay, F., Shirali, P., Verdin, A., \& Lounès-Hadj Sahraoui, A. (2015). Arbuscular mycorrhizal fungal inoculation protects Miscanthus $\times$ giganteus against trace element toxicity in a highly metalcontaminated site. Science of the Total Environment, 527-528, 91-99. https://doi. org/10.1016/j.scitotenv.2015.04.116.

Gaur, A., \& Adholeya, A. (2004). Prospects of arbuscular mycorrhizal fungi in phytoremediation of heavy metal contaminated soils. Current Science, 86(4), 528-534. https://www.jstor.org/stable/24107905.

Geletukha, G. G., Zheliezna, T. A., Tryboi, O. V., \& Bashtovyi, A. I. (2016). Analysis of criteria for the sustainable development of bioenergy. UABio Position Paper, 17, 30. https://doi.org/10.31472/ihe.6.2016.07.

Gerst, E. A. (2014). A novel approach to use second generation biofuel crop plants (Camelina sativa, Miscanthus $\times$ giganteus, and Panicum virgatum) to remediate abandoned mine lands in Pennsylvania [Master, The Pennsylvania State University]. https://etda. libraries.psu.edu/catalog/21365. 
Gleeson, A. M. (2007). Phytoextraction of lead from contaminated soil by Panicum virgatum L. (switchgrass) and associated growth responses [Master, Queen's University].

Greef, J., \& Deuter, M. (1993). Syntaxonomy of Miscanthus x giganteus Greef et Deu. Angewandte Botanik, 67(3/4), 87-90.

Gudichuttu, V. (2014). Phytostabilization of multi-metal contaminated mine waste materials: Long-term monitoring of influence of soil amendments on soil properties, plants, and biota and the avoidance response of earthworms [Thesis, Kansas State University]. https://krex.k-state.edu/dspace/handle/2097/16989.

Guo, H., Wu, Y., Hong, C., Chen, H., Chen, X., Zheng, B., Jiang, D., \& Qin, W. (2017). Enhancing digestibility of Miscanthus using lignocellulolytic enzyme produced by Bacillus. Bioresource Technology, 245, 1008-1015. https://doi.org/10.1016/j. biortech.2017.09.034.

Heaton, E. A., Dohleman, F. G., \& Long, S. P. (2008). Meeting US biofuel goals with less land: The potential of Miscanthus. Global Change Biology, 14(9), 2000-2014. https://doi.org/10.1111/j.1365-2486.2008.01662.x.

Herrera, A. M., \& Dudley, T. L. (2003). Reduction of riparian arthropod abundance and diversity as a consequence of giant reed (Arundo donax) invasion. Biological Invasions, 5(3), 167-177. https://doi.org/10.1023/A:1026190115521.

Hettiarachchi, G. M., Pierzynski, G. M., \& Ransom, M. D. (2000). In situ stabilization of soil lead using phosphorus and manganese oxide. Environmental Science $\mathcal{E}$ Technology, 34(21), 4614-4619. https://doi.org/10.1021/es001228p.

Holder, A. J., Clifton-Brown, J., Rowe, R., Robson, P., Elias, D., Dondini, M., McNamara, N. P., Donnison, I. S., \& McCalmont, J. P. (2019). Measured and modelled effect of land-use change from temperate grassland to Miscanthus on soil carbon stocks after 12 years. GCB Bioenergy, 11(10), 1173-1186. https://doi.org/10.1111/gcbb.12624.

Hromádko, L., Vranová, V., Techer, D., Laval-Gilly, P., Rejšek, K., Formánek, P., \& Falla, J. (2014). Composition of root exudates of Miscanthus x giganteus Greef et Deu. Acta Universitatis Agriculturae et Silviculturae Mendelianae Brunensis, 58(1), 71-76.

Hu, Y., Schäfer, G., Duplay, J., \& Kuhn, N. J. (2018). Bioenergy crop induced changes in soil properties: A case study on Miscanthus fields in the Upper Rhine Region. PLoS One, 13(7), e0200901. https://doi.org/10.1371/journal.pone.0200901.

Hunt, A. J., Anderson, C. W. N., Bruce, N., García, A. M., Graedel, T. E., Hodson, M., Meech, J. A., Nassar, N. T., Parker, H. L., Rylott, E. L., Sotiriou, K., Zhang, Q., \& Clark, J. H. (2014). Phytoextraction as a tool for green chemistry. Green Processing and Synthesis, 3(1), 3-22. https://doi.org/10.1515/gps-2013-0103.

Jeguirim, M., \& Trouvé, G. (2009). Pyrolysis characteristics and kinetics of Arundo donax using thermogravimetric analysis. Bioresource Technology, 100(17), 40264031. https://doi.org/10.1016/j.biortech.2009.03.033.

Jiang, H., Zhao, X., Fang, J., \& Xiao, Y. (2018). Physiological responses and metal uptake of Miscanthus under cadmium/arsenic stress. Environmental Science and Pollution Research, 25(28), 28275-28284. https://doi.org/10.1007/s11356-018-2835-z.

Johnson, D. (2014). Induced phytoextraction of lead from contaminated urban soil through manipulation of rhizosphere and plant biogeochemical functions in switchgrass (Panicum virgatum) [Master of Science in Integrative Biology Theses, Kennesaw State University]. https://digitalcommons.kennesaw.edu/ integrbiol_etd/2.

Juang, K.-W., \& Lee, D. Y. (2010). Prediction of cadmium removal from highly contaminated soils by phytoextraction with different switchgrass cultivars, 19th World Congress of Soil Science, Soil Solutions for a Changing World, Brisbane, Australia. 
Kabi, F., Bareeba, F. B., Havrevoll, Ø., \& Mpofu, I. D. T. (2005). Evaluation of protein degradation characteristics and metabolisable protein of elephant grass (Pennisetum purpureum) and locally available protein supplements. Livestock Production Science, 95(1), 143-153. https://doi.org/10.1016/j.livprodsci.2004.12.013.

Kasprzyk, A., Leszczuk, A., Domaciuk, M., \& Szczuka, E. (2013). Stem morphology of the Sida hermaphrodita (L.) Rusby (Malvaceae). Modern Phytomorphology, 4, $25-25$.

Kausar, S., Mahmood, Q., Raja, I. A., Khan, A., Sultan, S., Gilani, M. A., \& Shujaat, S. (2012). Potential of Arundo donax to treat chromium contamination. Ecological Engineering, 42, 256-259. https://doi.org/10.1016/j.ecoleng.2012.02.019.

Kharytonov, M., Pidlisnyuk, V., Stefanovska, T., Babenko, M., Martynova, N., \& Rula, I. (2019). The estimation of Miscanthus $\times$ giganteus' adaptive potential for cultivation on the mining and post-mining lands in Ukraine. Environmental Science and Pollution Research, 26(3), 2974-2986.

Kocoń, A., \& Matyka, M. (2012). Phytoextractive potential of Miscanthus $\times$ giganteus and Sida hermaphrodita growing under moderate pollution of soil with $\mathrm{Zn}$ and Pb. Journal of Food, Agriculture and Environment, 10(2 part 3), 1253-1256. https:// www.cabdirect.org/cabdirect/abstract/20123224099.

Kołodziej, B., Antonkiewicz, J., \& Sugier, D. (2016). Miscanthus $\times$ giganteus' as a biomass feedstock grown on municipal sewage sludge. Industrial Crops and Products, 81, 72-82. https://doi.org/10.1016/j.indcrop.2015.11.052.

Krzywy-Gawrońska, E. (2012). The effect of industrial wastes and municipal sewage sludge compost on the quality of virginia fanpetals (Sida hermaphrodita Rusby) biomass Part 1. Macroelements content and their uptake dynamics. Polish Journal of Chemical Technology, 14(2), 9-15. https://doi.org/10.2478/v10026-012-0064-7.

Kvak, V., Stefanovska, T., Pidlisnyuk, V., Alasmary, Z., \& Kharytonov, M. (2018). The long-term assessment of Miscanthus x giganteus cultivation in the Forest-Steppe zone of Ukraine. INMATEH-Agricultural Engineering, 54(1), 113-120. https:// www.cabdirect.org/cabdirect/abstract/20183366934.

Laperche, V., Traina, S. J., Gaddam, P., \& Logan, T. J. (1996). Chemical and mineralogical characterizations of $\mathrm{Pb}$ in a contaminated soil: Reactions with synthetic apatite. Environmental Science E Technology, 30(11), 3321-3326. https://doi. org/10.1021/es960141u.

Lasat, M. (1999). Phytoextraction of metals from contaminated soil: A review of plant/ soil/metal interaction and assessment of pertinent agronomic issues. Journal of Hazardous Substance Research, 2(1). https://doi.org/10.4148/1090-7025.1015.

Lewandowski, I., Clifton-Brown, J. C., Scurlock, J. M. O., \& Huisman, W. (2000). Miscanthus: European experience with a novel energy crop. Biomass and Bioenergy, 19(4), 209-227. https://doi.org/10.1016/S0961-9534(00)00032-5.

Lewandowski, I., Clifton-Brown, J., Trindade, L. M., van der Linden, G. C., Schwarz, K.-U., Müller-Sämann, K., Anisimov, A., Chen, C.-L., Dolstra, O., Donnison, I. S., Farrar, K., Fonteyne, S., Harding, G., Hastings, A., Huxley, L. M., Iqbal, Y., Khokhlov, N., Kiesel, A., Lootens, P., ... Kalinina, O. (2016). Progress on optimizing Miscanthus biomass production for the European bioeconomy: Results of the EU FP7 Project OPTIMISC. Frontiers in Plant Science, 7. https://doi.org/10.3389/fpls.2016.01620.

Lewandowski, I., Schmidt, U., \& Faaij, A. P. C. (2005). Perennial crops are the most sustainable option for biomass production-A comparison of the efficiency and multiple land use options of perennial and annual biomass crops. Industrial Ecology for a Sustainable Future (Abstract Book Oral Sessions), 144-146. 
Li, Y.-M., Chaney, R., Brewer, E., Roseberg, R., Angle, J. S., Baker, A., Reeves, R., \& Nelkin, J. (2003). Development of a technology for commercial phytoextraction of nickel: Economic and technical considerations. Plant and Soil, 249(1), 107-115. https://doi.org/10.1023/A:1022527330401.

Li, C., Wang, Q. H., Xiao, B., \& Li, Y. F. (2011). Phytoremediation potential of switchgrass (Panicum virgatum L.) for Cr-polluted soil. 2011 International Symposium on Water Resource and Environmental Protection (ISWREP), Xi'an. https://doi. org/10.1109/ISWREP.2011.5893582.

López-Chuken, U. J., \& Young, S. D. (2005). Plant screening of halophyte species for cadmium phytoremediation. Zeitschrift für Naturforschung, 60(3/4), 236-243.

Lotfy, S. M., \& Mostafa, A. Z. (2014). Phytoremediation of contaminated soil with cobalt and chromium. Journal of Geochemical Exploration, 144, 367-373. https:// doi.org/10.1016/j.gexplo.2013.07.003.

Lotfy, S. M., Mostafa, A. Z., \& Abdel-Sabour, M. F. (2012). Phytoextraction of cadmium from and zinc contaminated soils. 3rd International Conference on Radiation Sciences and Applications, Hurghada, Egypt.

Ma, L. Q., Komar, K. M., Tu, C., Zhang, W., Cai, Y., \& Kennelley, E. D. (2001). A fern that hyperaccumulates arsenic. Nature, 409(6820), 579-579. https://doi. org $/ 10.1038 / 35054664$.

Malayeri, B. E., Chehregani, A., Yousefi, N., \& Lorestani, B. (2008). Identification of the hyper accumulator plants in copper and iron mine in Iran. Pakistan Journal of Biological Sciences : PJBS, 11(3), 490-492. https://doi.org/10.3923/pjbs.2008.490.492.

Mamirova, A., Pidlisnyuk, V., Amirbekov, A., Ševců, A., \& Nurzhanova, A. (2020). Phytoremediation potential of Miscanthus sinensis And. In organochlorine pesticides contaminated soil amended by Tween 20 and Activated carbon. Environmental Science and Pollution Research. https://doi.org/10.1007/ s11356-020-11609-y.

Matyka, M., \& Kuś, J. (2016). Influence of soil quality for yielding and biometric features of Miscanthus x giganteus. Polish Journal of Environmental Studies, 25(1), 213-219. https://doi.org/10.15244/pjoes/60108.

Maughan, M., Bollero, G., Lee, D. K., Darmody, R., Bonos, S., Cortese, L., Murphy, J., Gaussoin, R., Sousek, M., Williams, D., Williams, L., Miguez, F., \& Voigt, T. (2012). Miscanthus $\times$ giganteus productivity: The effects of management in different environments. GCB Bioenergy, 4(3), 253-265. https://doi. org/10.1111/j.1757-1707.2011.01144.x.

McCalmont, J. P., Hastings, A. F. S. J., McNamara, N. P., Richter, G. M., Robson, P., Donnison, I. S., \& Clifton-Brown, J. C. (2015). Environmental costs and benefits of growing Miscanthus for bioenergy in the UK. GCB Bioenergy, 9, 489-507. https://doi.org/10.1111/gcbb.12294.

Medlin, E. A. (1997). An in vitro method for estimating the relative bioavailability of lead in humans [Master's thesis. Department of Geological Sciences, University of Colorado, Boulder, CO, USA].

Mi, J., Liu, W., Zhao, X., Kang, L., Lin, C., Yan, J., \& Sang, T. (2018). $\mathrm{N}_{2} \mathrm{O}$ and $\mathrm{CH}_{4}$ emission from Miscanthus energy crop fields in the infertile Loess Plateau of China. Biotechnology for Biofuels, 11(1), 321. https://doi.org/10.1186/s13068-018-1320-8.

Miguez, F. E., Villamil, M. B., Long, S. P., \& Bollero, G. A. (2008). Meta-analysis of the effects of management factors on Miscanthus $\times$ giganteus growth and biomass production. Agricultural and Forest Meteorology, 148(8), 1280-1292. https://doi. org/10.1016/j.agrformet.2008.03.010. 
Moser, L., \& Vogel, K. (1995). Switchgrass, big bluestem, and indiangrass. Publications from USDA-ARS/UNL Faculty. https://digitalcommons.unl.edu/ usdaarsfacpub/2098.

Murányi, A., \& Ködöböcz, L. (2008). Heavy metal uptake by plants in different phytoremediation treatments. VII Alps-Adria Scientific Workshop, Stara Lesna, Slovakia, 36, 387-390.

Narayanan, M., Erickson, L. E., \& Davis, L. C. (1999). Simple plant-based design strategies for volatile organic pollutants. Environmental Progress, 18(4), 231-242. https://doi.org/10.1002/ep.670180409.

Nsanganwimana, F., Pourrut, B., Waterlot, C., Louvel, B., Bidar, G., Labidi, S., Fontaine, J., Muchembled, J., Lounès-Hadj Sahraoui, A., Fourrier, H., \& Douay, F. (2015). Metal accumulation and shoot yield of Miscanthus $\times$ giganteus growing in contaminated agricultural soils: Insights into agronomic practices. Agriculture, Ecosystems E Environment, 213, 61-71. https://doi.org/10.1016/j.agee.2015.07.023.

Nurzhanova, A., Pidlisnyuk, V., Abit, K., Nurzhanov, C., Kenessov, B., Stefanovska, T., \& Erickson, L. (2019). Comparative assessment of using Miscanthus $\times$ giganteus for remediation of soils contaminated by heavy metals: A case of military and mining sites. Environmental Science and Pollution Research, 26(13), 13320-13333. https://doi.org/10.1007/s11356-019-04707-z.

Ociepa, E. (2011). The effect of fertilization on yielding and heavy metals uptake by maize and Virginia fanpetals (Sida hermaphrodita). Archives of Environmental Protection, 37(2), 123-129.

Ogunkunle, C. O., Fatoba, P. O., Oyedeje, A. O., \& Awotoye, O. O. (2014). Assessing the heavy metal transfer and translocation by Sida acuta and Pennisetum purpureum for phytoremediation purposes. Albanian Journal of Agricultural Science, 13(1), 71-80.

Pandey, V. C., \& Bajpai, O. (2019). Chapter 1-Phytoremediation: From theory toward practice. In V. C. Pandey \& K. Bauddh (Eds.), Phytomanagement of Polluted Sites (pp. 1-49), Elsevier, New York. https://doi.org/10.1016/B978-0-12-813912-7.00001-6.

Papazoglou, E. G., Karantounias, G. A., Vemmos, S. N., \& Bouranis, D. L. (2005). Photosynthesis and growth responses of giant reed (Arundo donax L.) to the heavy metals Cd and Ni. Environment International, 31(2), 243-249. https://doi. org/10.1016/j.envint.2004.09.022.

Papazoglou, E. G., Serelis, K. G., \& Bouranis, D. L. (2007). Impact of high cadmium and nickel soil concentration on selected physiological parameters of Arundo donax L. European Journal of Soil Biology, 43(4), 207-215. https://doi.org/10.1016/j. ejsobi.2007.02.003.

Parrish, D. J., Casler, M. D., \& Monti, A. (2012). The evolution of switchgrass as an energy crop. In A. Monti (Ed.), Switchgrass: A Valuable Biomass Crop for Energy (pp. 1-28), Springer, London. https://doi.org/10.1007/978-1-4471-2903-5_1.

Pavel, P.-B., Puschenreiter, M., Wenzel, W. W., Diacu, E., \& Barbu, C. H. (2014). Aided phytostabilization using Miscanthus sinensis $x$ giganteus on heavy metal-contaminated soils. Science of the Total Environment, 479-480, 125-131. https://doi. org/10.1016/j.scitotenv.2014.01.097.

Pidlisnyuk, V., Mamirova, A., Pranaw, K., Shapoval, P. Y., Trögl, J., \& Nurzhanova, A. (2020a). Potential role of plant growth-promoting bacteria in Miscanthus $\times$ giganteus phytotechnology applied to the trace elements contaminated soils. International Biodeterioration E Biodegradation, 155, 105103. https:// doi.org/10.1016/j.ibiod.2020.105103. 
Pidlisnyuk, V., Stefanovska, T., Lewis, E. E., Erickson, L. E., \& Davis, L. C. (2014). Miscanthus as a productive biofuel crop for phytoremediation. Critical Reviews in Plant Sciences, 33(1), 1-19. https://doi.org/10.1080/07352689.2014.8 47616.

Pidlisnyuk, V. V., Erickson, L., Stefanovska, T., Popelka, J., Hettiarachchi, G., Davis, L., \& Trögl, J. (2019). Potential phytomanagement of military polluted sites and biomass production using biofuel crop Miscanthus $\times$ giganteus. Environmental Pollution, 249, 330-337. https://doi.org/10.1016/j.envpol.2019.03.018.

Pidlisnyuk, V. V., Erickson, L. E., Trögl, J., Shapoval, P. Y., Popelka, J., Davis, L. C., Stefanovska, T. R., \& Hettiarachchi, G. M. (2018). Metals uptake behaviour in Miscanthus $\times$ giganteus plant during growth at the contaminated soil from the military site in Sliač, Slovakia. Polish Journal of Chemical Technology, 20(2), 1-7. https://doi.org/10.2478/pjct-2018-0016.

Pidlisnyuk, V. V., Shapoval, P., Zgorelec, Z., Stefanovska, T., \& Zhukov, O. (2020b). Multiyear phytoremediation and dynamic of foliar metal(loid)s concentration during application of Miscanthus x giganteus Greef et Deu to polluted soil from Bakar, Croatia. Environmental Science and Pollution Research, 27, 31446-31457. https://doi.org/10.1007/s11356-020-09344-5.

Pilu, R., Manca, A., \& Landoni, M. (2013). Arundo donax as an energy crop: Pros and cons of the utilization of this perennial plant. Maydica, 58(1), 54-59. https:// journals-crea.4science.it/index.php/maydica/article/view/916.

Pivetz, B. E. (2001). Phytoremediation of contaminated soil and ground water at hazardous waste sites. US Environmental Protection Agency, Office of Research and Development.

Pogrzeba, M., Krzyżak, J., \& Sas-Nowosielska, A. (2013). Environmental hazards related to Miscanthus $\times$ giganteus cultivation on heavy metal contaminated soil. E3S Web of Conferences, 1, 29006. https://doi.org/10.1051/ e3sconf/20130129006.

Pranaw, K., Pidlisnyuk, V., Trögl, J., \& Malinská, H. (2020). Bioprospecting of a novel plant growth-promoting bacterium Bacillus altitudinis KP-14 for enhancing Miscanthus $\times$ giganteus growth in metals contaminated soil. Biology, 9(9), 305. https://doi.org/10.3390/biology9090305.

Pulford, I. D., \& Watson, C. (2003). Phytoremediation of heavy metal-contaminated land by trees-A review. Environment International, 29(4), 529-540. https://doi. org/10.1016/S0160-4120(02)00152-6.

Rascio, N., \& Navari-Izzo, F. (2011). Heavy metal hyperaccumulating plants: How and why do they do it? And what makes them so interesting? Plant Science, 180(2), 169-181. https://doi.org/10.1016/j.plantsci.2010.08.016.

Rinehart, L. (2006). Switchgrass as a bioenergy crop. National Center for Appropriate Technology, http://Attra.Ncat.Org/Attra-Pub/PDF/Switchgrass.Pdf.

Robinson, B. H., Bañuelos, G., Conesa, H. M., Evangelou, M. W. H., \& Schulin, R. (2009). The phytomanagement of trace elements in soil. Critical Reviews in Plant Sciences, 28(4), 240-266. https://doi.org/10.1080/07352680903035424.

Roik, M., Sinchenko, V., Purkin, V., Kvak, V., \& Humentik, M. (Eds.). (2019). Miscanthus in Ukraine. FOP Yamchinskiy Press.

Ruby, M. V., Davis, A., Schoof, R., Eberle, S., \& Sellstone, C. M. (1996). Estimation of lead and arsenic bioavailability using a physiologically based extraction test. Environmental Science \& Technology, 30(2), 422-430. https://doi.org/10.1021/ es950057z. 
Sabeen, M., Mahmood, Q., Irshad, M., Fareed, I., Khan, A., Ullah, F., Hussain, J., Hayat, Y., \& Tabassum, S. (2013). Cadmium phytoremediation by Arundo donax L. from contaminated soil and water. BioMed Research International, 2013. https://doi. org $/ 10.1155 / 2013 / 324830$.

Sagehashi, M., Liu, C., Fujii, T., Fujita, H., Sakai, Y., Hu, H.-Y., \& Sakoda, A. (2011). Cadmium removal by the hydroponic culture of giant reed (Arundo donax) and its concentration in the plant. Journal of Water and Environment Technology, 9(2), 121-127. https://doi.org/10.2965/jwet.2011.121.

Sankaran, R. P., \& Ebbs, S. D. (2007). Cadmium accumulation in deer tongue grass (Panicum clandestinum L.) and potential for trophic transfer to microtine rodents. Environmental Pollution, 148(2), 580-589. https://doi.org/10.1016/j. envpol.2006.11.025.

Schmidt, C. S., Mrnka, L., Frantík, T., Lovecká, P., \& Vosátka, M. (2018). Plant growth promotion of Miscanthus $\times$ giganteus by endophytic bacteria and fungi on nonpolluted and polluted soils. World Journal of Microbiology and Biotechnology, 34(3), 48. https://doi.org/10.1007/s11274-018-2426-7.

Shahandeh, H., \& Hossner, L. (2000). Plant screening for chromium phytoremediation. International Journal of Phytoremediation, 2(1), 31-51. https://doi. org/10.1080/15226510008500029.

Shim, J., Babu, A. G., Velmurugan, P., Shea, P. J., \& Oh, B.-T. (2014). Pseudomonas fluorescens $\mathrm{JH} 70-4$ promotes $\mathrm{Pb}$ stabilization and early seedling growth of Sudan grass in contaminated mining site soil. Environmental Technology, 35(20), 25892596. https://doi.org/10.1080/09593330.2014.913691.

Sidella, S. (2014). Adaptability, biomass yield, and phytoremediation of Arundo donax L. on marginal lands: Salt, dry and lead-contaminated soils [Doctoral Thesis, University of Catania]. http://dspace.unict.it:8080/handle/10761/1605.

Solís-Dominguez, F. A., White, S. A., Hutter, T. B., Amistadi, M. K., Root, R. A., Chorover, J., \& Maier, R. M. (2012). Response of key soil parameters during compost-assisted phytostabilization in extremely acidic tailings: Effect of plant species. Environmental Science \& Technology, 46(2), 1019-1027. https://doi. org/10.1021/es202846n.

Tari, I., Poór, P., Ördög, A., Székely, A., Laskay, G., \& Bagi, I. (2013). Enhanced biomass production in sudangrass induced by co-treatment with copper and EDTA. Environmental and Experimental Biology, 11, 151-157.

Teel, A. (2003). Management guide for the production of switchgrass for biomass fuel in southern Iowa. PM 1710, May 2003, 3 pages. https://www.agmrc.org/media/ cms/PM1710_097EE99B56173.pdf

Tordoff, G. M., Baker, A. J. M., \& Willis, A. J. (2000). Current approaches to the revegetation and reclamation of metalliferous mine wastes. Chemosphere, 41(1), 219 228. https://doi.org/10.1016/S0045-6535(99)00414-2.

Tryboi, O. V. (2018). Efficient biomass value chains for heat production from energy crops in Ukraine. Energetika, 64(2), Article 2. https://doi.org/10.6001/energetika. v64i2.3782.

USEPA. (1998). A citizen's guide to phytoremediation (EPA 542-F-98-011). U.S. Environmental Protection Agency, Office of Solid Waste and Emergency Response.

USEPA. (2000). Introduction to phytoremediation (EPA 600/R-99/107). U.S. Environmental Protection Agency. 
Vassey, T. L., George, J. R., \& Mullen, R. E. (1985). Early-, mid-, and late-spring establishment of switchgrass at several seeding rates. Agronomy Journal, 77(2), 253-257. https://doi.org/10.2134/agronj1985.00021962007700020018x.

Vogel, K. P. (1987). Seeding rates for establishing big bluestem and switchgrass with preemergence atrazine applications. Agronomy Journal, 79(3), 509-512. https:// doi.org/10.2134/agronj1987.00021962007900030021x.

Vogel, K. P. (2000). Improving warm-season forage grasses using selection, breeding, and biotechnology. In Kenneth J. Moore \& Bruce E. Anderson (Eds.), Native Warm-Season Grasses: Research Trends and Issues (pp. 83-106). John Wiley \& Sons, Ltd. https://doi.org/10.2135/cssaspecpub30.c6.

Wang, C., Kong, Y., Hu, R., \& Zhou, G. (2020). Miscanthus: A fast-growing crop for environmental remediation and biofuel production. GCB Bioenergy, 13, 58-69. https://doi.org/10.1111/gcbb.12761.

Wijesekara, H., Bolan, N. S., Vithanage, M., Xu, Y., Mandal, S., Brown, S. L., Hettiarachchi, G. M., Pierzynski, G. M., Huang, L., Ok, Y. S., Kirkham, M. B., Saint, C. P., \& Surapaneni, A. (2016). Chapter Two - Utilization of biowaste for mine spoil rehabilitation. In D. L. Sparks (Ed.), Advances in Agronomy (Vol. 138, pp. 97-173). Academic Press, Cambridge, MA. https://doi.org/10.1016/ bs.agron.2016.03.001.

Wilkins, C. (1997). The uptake of copper, arsenic and zinc by MiscanthusEnvironmental implications for use as an energy crop. Aspects of Applied Biology, No. 49, 335-340. https://www.cabdirect.org/cabdirect/abstract/19970707775.

Wolf, D. D., \& Fiske, D. A. (2009). Planting and managing switchgrass for forage, wildlife, and conservation. https://vtechworks.lib.vt.edu/handle/10919/50258.

Xia, H. P. (2004). Ecological rehabilitation and phytoremediation with four grasses in oil shale mined land. Chemosphere, 54(3), 345-353. https://doi.org/10.1016/ S0045-6535(03)00763-X.

Yang, M., Xiao, X., Miao, X., Guo, Z., \& Wang, F. (2012). Effect of amendments on growth and metal uptake of giant reed (Arundo donax L.) grown on soil contaminated by arsenic, cadmium and lead. Transactions of Nonferrous Metals Society of China, 22(6), 1462-1469. https://doi.org/10.1016/S1003-6326(11)61342-3.

Yang, S., Liao, B., Li, J., Guo, T., \& Shu, W. (2010). Acidification, heavy metal mobility and nutrient accumulation in the soil-plant system of a revegetated acid mine wasteland. Chemosphere, 80(8), 852-859. https://doi.org/10.1016/j. chemosphere.2010.05.055.

Zema, D. A., Bombino, G., Andiloro, S., \& Zimbone, S. M. (2012). Irrigation of energy crops with urban wastewater: Effects on biomass yields, soils and heating values. Agricultural Water Management, 115, 55-65. https://doi.org/10.1016/j. agwat.2012.08.009.

Zgorelec, Ž. (2009). Phytoaccumulation of metals and metalloids from soil polluted by coal ash [University of Zagreb]. https://www.bib.irb.hr/439719?rad=439719.

Zgorelec, Z., Bilandzija, N., Knez, K., Galic, M., \& Zuzul, S. (2020). Cadmium and mercury phytostabilization from soil using Miscanthus $\times$ giganteus. Scientific Reports, 10(1), 6685. https://doi.org/10.1038/s41598-020-63488-5.

Zhang, J., Yang, S., Huang, Y., \& Zhou, S. (2015). The tolerance and accumulation of Miscanthus sacchariflorus (maxim.) Benth., an energy plant species, to cadmium. International Journal of Phytoremediation, 17(6), 538-545. https://doi.org/10.1080/ 15226514.2014.922925. 
Zhang, X., Xia, H., Li, Z., Zhuang, P., \& Gao, B. (2010). Potential of four forage grasses in remediation of $\mathrm{Cd}$ and $\mathrm{Zn}$ contaminated soils. Bioresource Technology, 101(6), 2063-2066. https://doi.org/10.1016/j.biortech.2009.11.065.

Zhang, Y., Xu, C., Lu, J., Yu, H., \& Xia, T. (2020). An effective strategy for dual enhancements on bioethanol production and trace metal removal using Miscanthus straws. Industrial Crops and Products, 152, 112393. https://doi.org/10.1016/j. indcrop.2020.112393.

Zhuang, P., Shu, W., Li, Z., Liao, B., Li, J., \& Shao, J. (2009). Removal of metals by sorghum plants from contaminated land. Journal of Environmental Sciences, 21(10), 1432-1437. https://doi.org/10.1016/S1001-0742(08)62436-5.

Żurek, G., Pogrzeba, M., Rybka, K., \& Prokopiuk, K. (2013). Suitability of grass species for phytoremediation of soils polluted with heavy-metals. In S. Barth \& D. Milbourne (Eds.), Breeding Strategies for Sustainable Forage and Turf Grass Improvement (pp. 245-248), Springer, Dordrecht.

Zwonitzer, J. C., Pierzynski, G. M., \& Hettiarachchi, G. M. (2003). Effects of phosphorus additions on lead, cadmium, and zinc bioavailabilities in a metal-contaminated soil. Water, Air, \& Soil Pollution, 143, 193-209. https://doi. org/10.1023/A:1022810310181. 